\title{
Transcranial direct current stimulation as a tool in the study of sensory-perceptual processing
}

\author{
Thiago L. Costa ${ }^{1,2}$ • Olivia M. Lapenta ${ }^{2}$. \\ Paulo S. Boggio ${ }^{2}$ - Dora F. Ventura ${ }^{1}$
}

Published online: 3 July 2015

(C) The Psychonomic Society, Inc. 2015

\begin{abstract}
Transcranial direct current stimulation (tDCS) is a non-invasive neuromodulatory technique with increasing popularity in the fields of basic research and rehabilitation. It is an affordable and safe procedure that is beginning to be used in the clinic, and is a tool with potential to contribute to the understanding of neural mechanisms in the fields of psychology, neuroscience, and medical research. This review presents examples of investigations in the fields of perception, basic sensory processes, and sensory rehabilitation that employed tDCS. We highlight some of the most relevant efforts in this area and discuss possible limitations and gaps in contemporary tDCS research. Topics include the five senses, pain, and multimodal integration. The present work aims to present the state of the art of this field of research and to inspire future investigations of perception using tDCS.
\end{abstract}

Keywords tDCS $\cdot$ Perception $\cdot$ Rehabilitation $\cdot$ Brain stimulation

\section{Introduction}

In contemporary psychology and neuroscience research, better understanding of the brain-behavior relationship is a

Thiago L. Costa

e.thiagocosta@gmail.com

1 Departamento de Psicologia Experimental, Universidade São Paulo, São Paulo, Brazil

2 Laboratório de Neurociência Cognitiva e Social, Universidade Presbiteriana Mackenzie, São Paulo, Brazil central goal. Given that, the field can profit very much from directly interfering with brain activity and measuring the behavioral outcome. In this article we argue that transcranial direct current stimulation (tDCS) is a valuable tool for this purpose, and we show a number of examples of possible applications. Contemporary research mostly focuses on correlational methods (such as imaging and electroencephalography) and behavioral evaluation. Here we argue and illustrate that the combination of these methods and direct brain stimulation can bring important insight for current clinical and basic research. This review is organized into four main sections: (1) an introduction to tDCS mechanisms of action and parameters; (2) a review of the state of the art in research of different sensory modalities, pain, and multimodal integration; (3) a critical account on how our understanding of tDCS may profit from the use of more sophisticated measures and psychophysical methods; and (4) a summary of the most popular approaches in tDCS research. We have included tables at the end of each section of the review summarizing all the tDCS studies reviewed here. The tables include all the relevant parameters of tDCS stimulation and the outcome measures used, so that important information about these studies can be quickly accessed and compared.

\section{What is transcranial direct current stimulation (tDCS) and how does it work?}

Reports of the non-invasive delivery of electric currents as a neuromodulatory intervention stemback to classical antiquity (Priori, 2003). However, only in the 1960s did combined electrophysiologic and behavioral data confirm that electrical stimulation over the scalp could induce site-specific changes on brain activity in a polarity-dependent manner (Creutzfeldt et al. 1962; Landau et al., 1964). Recently, an elegant non- 
invasive brain stimulation procedure using low-intensity currents was introduced and caused a growth of interest in the field (Nitsche \& Paulus, 2000; Nitsche et al., 2008). Known as transcranial direct current stimulation (tDCS), this procedure is helping to elucidate brain-behavior relationships in patients and healthy humans, and it has been shown to have substantial neurorehabilitation potential. Here we review the current state of sensation and perception research using tDCS as a tool.

Contemporary tDCS procedures may vary in specific details of the technique. Generally, they are based on the application of unidirectional constant current over superficial cortical areas via electrodes placed on target areas of the scalp. Most frequently, these are large electrodes $\left(25-35 \mathrm{~cm}^{2}\right)$ and the current intensity varies between 1 and $2 \mathrm{~mA}$ (Nitsche et al., 2008; Zaghi et al. 2009).

The current flows from the anode to the cathode electrode. Thus, depending on the electrode positioning, the resting membrane potential of neurons in an area may be modulated to be closer or more distant from the firing threshold. Apparently tDCS does not directly induce action potentials; instead it modulates the excitability of the cortex within the physiologic range (Bindman et al., 1964; Nitsche et al., 2008). Generally the anode electrode will result in facilitation and the cathode in inhibition of the neural firing (Nitsche \& Paulus, 2000), although parameters and other issues may result in the opposite outcome, as we discuss below.

Besides current direction, the main parameters to define in tDCS protocols are electrode positioning (generally following the 10-20 EEG system), current density (electric current per electrode area), stimulation length, number of sessions, and whether the stimulation was delivered during a task (online tDCS) or before the task (offline tDCS). Extensive data suggest that this is a safe procedure that involves mild and transient adverse effects (Brunoni et al., 2012; Nitsche et al., 2008). In a systematic review of tDCS experiments in humans, Brunoni et al. (2012) found that $56 \%$ of the studies mentioned adverse effects but these were limited to itching or tingling under the electrodes, headache, and discomfort. These adverse effects were also present in participants receiving sham tDCS, thus suggesting that the major cause of side effects may not be the current itself.

The moderate adverse effects related to tDCS reflect the safety parameters adopted by researches. In general, current densities range from 0.028 to $0.06 \mathrm{~mA} / \mathrm{cm}^{2}$, which are at least 400 times lower than the current density shown by McCreery et al. (1990) as being able to induce neural tissue damage. It is noteworthy that McCreery et al. placed electrodes over the brain, when in fact tDCS is applied over the scalp, using saline-soaked non-metallic electrodes. These methods avoid toxic release caused by brain-electrode contact thus minimizing brain lesion possibilities (Nitsche et al. 2003a, b) and reduce chemical reactions with the skin. The total amount of current delivered during a session should also be considered.
For instance, if we apply $2 \mathrm{~mA}$ through $35 \mathrm{~cm}^{2}$ during $30 \mathrm{~min}$, the total current delivered will be $0.103 \mathrm{C} / \mathrm{cm}^{2}$, a value 2100 times below the safety criteria (Yuen et al., 1981).

Recent studies have shown that tDCS does not induce either elevations of a neuronal damage marker (neuron-specific enolase) or edema in humans (Nitsche et al. 2003a, b, Nitsche et al. 2004a, b, Nitsche et al. 2008). Also, no maladaptive functional or structural changes were observed in evaluations using electroencelograms (EEGs) and functional magnetic resonance imaging (fMRI) (Iyer et al., 2005; Nitsche et al. 2004a, b). It is still not clear if repeated tDCS sessions over weeks and months can lead to undesirable side effects, and further research in that area is strongly advised.

\section{Mechanisms of action}

Although there is a consensus about the safety of tDCS procedures when standard parameters are used, the complete mechanisms of action are yet to be described. Two mechanisms appear to underlie tDCS effects and the main findings in this field may be summarized as follows: (1) in an initial stage $\mathrm{tDCS}$ effects might be explained by a modulation of the resting membrane potentials of the stimulated area, and (2) later its effects might be based on "LTP-like" and "LTD-like" plasticity mechanisms while (3) tDCS effects appear to be site specific but not site limited.

In summary we might say that anodal tDCS causes the resting membrane potential to become more positive, making the cell more likely to fire, while cathodal stimulation will do the opposite most of the time and will lead to hyperpolarization. This has been observed in many levels, most notably in a study that has delivered calcium and sodium channel blockers and observed the inactivation of anodal tDCS effects and no modulation of cathodal tDCS effects (since cathodal tDCS would act by hyperpolarizing the cells and the inactivation of calcium and sodium channels will have this very same effect; Nitsche et al. 2003a, b). More complex and less clear processes underlie tDCS effects on synaptic communication. Many works suggest that anodal tDCS may inhibit gammaaminobutyric acid (GABA; e.g., Nitsche et al. 2004a, b) while cathodal stimulation inhibits glutamate (e.g., Stagg et al., 2009). Nonetheless, most of the investigations have focused on motor cortex excitability and these processes might not translate to sensory functions, for instance. It is also important to note that many other neurotransmitters (such as dopamine, serotonin, and acetylcholine) might influence tDCS effects or be influenced by it. For detailed reviews of tDCS mechanisms of action see Stagg and Nitsche (2011), Medeiros et al. (2012), and Filmer, Dux and Mattingley (2014). In each of these reviews it is clear that although tDCS is a safe procedure and we have a reasonable picture of its mechanisms of action (Table 1), many relevant open questions still remain. 
Table 1 Main mechanisms of action underlying transcranial direct current stimulation (tDCS) effects (some exceptions may apply)

Anodal tDCS

Increases excitability in the stimulated area

Decreases voltage gradient between intracellular and extracellular medium

Inhibits neurotransmission by GABA

Induces "LTP-like" plasticity in the neocortex
Cathodal tDCS

Decreases excitability in the stimulated area

Increases voltage gradient between intracellular and extracellular medium Inhibits neurotransmission by glutamate

Induces "LTD-like" plasticity in the neocortex

GABA gamma-aminobutyric acid, LTP long-term potentiation, $L T D$ long-term depression

In spite of the many open questions regarding tDCS mechanisms of action, we know that most of its effects might be explained by approaching or distancing cells from its firing threshold, a phenomenon that is frequently described as a change in excitability, but could also be interpreted as a transient change in sensitivity. In fact, there is some psychophysical evidence supporting this interpretation. First, many studies show changes in thresholds (e.g., Antal et al., 2003a; Grundmann et al., 2011; Costa et al., 2012, 2015a). Some studies have also analyzed tDCS outcomes using a signal detection theory approach. These findings suggest that the changes in performance induced by tDCS are driven by changes in sensitivity and not changes in response criteria or bias. This was shown in the works of Olma et al. (2011) on contrast discrimination and Falcone et al. (2012) on the performance in a threat detection task.

\section{Focality and current flow}

Current flow and focality are crucial issues that must be kept in mind when discussing how tDCS works. tDCS is known to have a low spatial focality as it generally uses large electrodes and the current has to flow through highly conductive media with different levels of resistance. This might lead to a scenario where the electric current may spread way beyond the area below the stimulating electrode. A few groups have approached this issue with different models and distinct results. Miranda et al. (2006) used a circular head model and concluded that the maximum current density is achieved immediately below the stimulating electrode and gradually decreases at a distance from it. On the other hand, Bikson et al. (2012) developed a realistic head model and suggested that there is a higher current density between the electrodes than right beneath the electrodes. Later, Wagner et al. (2014) used a different realistic head model and found that most of the current density is concentrated below the electrodes, a finding similar to that of Miranda et al. (2006). Discussing differences between models is beyond the scope of this review, but there is a point where all agree: the current spreads away from the stimulating electrodes and might have functional effects in areas that are not being targeted at first. It is important to note that the distinctions in the works mentioned above might be accounted for by modeling parameters (see
Wagner et al., 2014 for a discussion) and this is a topic of current debate.

The role of the reference electrode is crucial with regard to tDCS focality. tDCS needs two electrodes with different polarities to work and both electrodes are functional throughout the stimulation session. Research results are frequently interpreted with a focus on the active electrode only and the role of the reference electrode is often not discussed. Let us consider an investigation that wants to target the early visual cortex. Placing the active electrode over Oz (using the 10-20 EEG system) would be the most popular choice, but this current has to flow to the reference electrode too. The researchers could choose different locations to place the reference electrode $(\mathrm{Cz}, \mathrm{Fz}$, or even on extracephalic sites, just to name a few possibilities; see Fig. 1a). The choice of reference electrode sites will have two consequences: it will affect the direction of current flow and it will also have a functional effect on the area where it is placed. In the cases where this functional effect is not desired and might act as a confounding factor, researchers have chosen reference electrode sites that are known to not be directly related
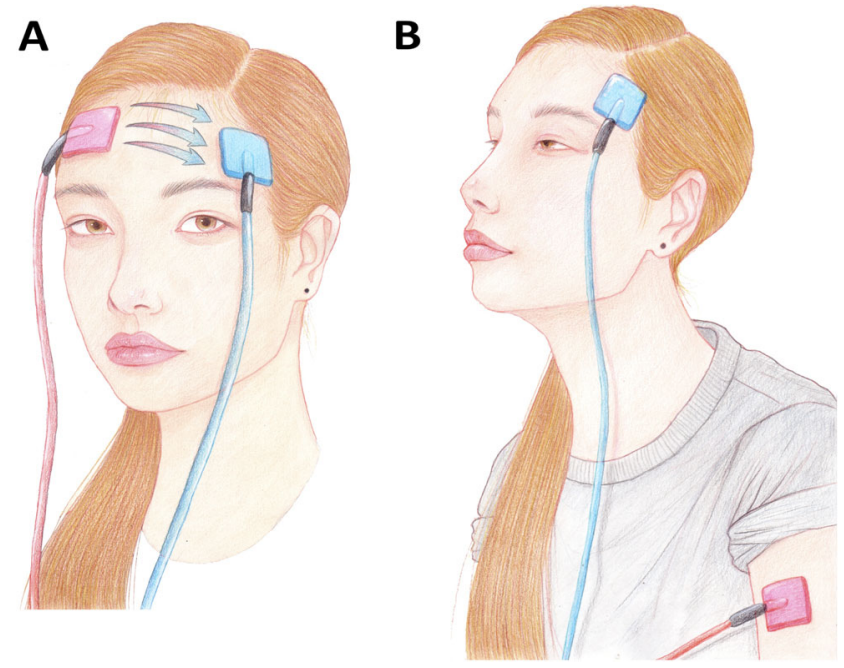

Fig. 1 Schematic representations of transcranial direct current stimulation (tDCS) procedures. As a convention, the current flows from the anode (presented here in red) to the cathode (blue). A typical montage for targeting the prefrontal cortex is presented in $\mathbf{A}$ and an extracephalic return electrode montage in $\mathbf{B}$. The pictures are for illustrative purposes only 
to the function that is being modulated. In many cases they have also used extracephalic electrodes (e.g., Ferrucci et al. 2008) or larger reference electrodes so that the current density is lower in this site in order to minimize its functional effects (e.g., Fregni et al. 2008).

Other alternatives have been suggested to address the limited focality of the standard tDCS procedure. For instance, some groups have used smaller electrodes. In one case, researchers customized electrode sizes and shapes based on individual MRI data (Tecchio et al., 2014).

These studies have yielded promising results but a new technique might be an alternative for these approaches in the future of tDCS. High-definition tDCS (HD-tDCS) has been developed with two goals: delivering a more focal stimulation and decreasing the functional relevance of the reference electrodes (Datta et al., 2009; Villamar et al., 2013). HD tDCS uses circular electrodes with approximately $1 \mathrm{~cm}$ diameter in a $4 \times 1$ montage, i.e. four reference electrodes placed equidistantly from an active electrode in the center (Fig. 2). Recent research has suggested that no significant effects are observed under the reference electrodes while an effect that is more focal but comparable in magnitude to the classic $5 \times 7 \mathrm{~cm}$ electrodes is induced under the active electrode (Edwards et al., 2013). Unfortunately very few studies have used HDTDCS so far and there is more limited information on parameters and expected results for thistechnique than for the classic tDCS montage used in numerous investigations. Nonetheless, HD-tDCS is a promising tool that will likely see an increase in popularity during the next few years.

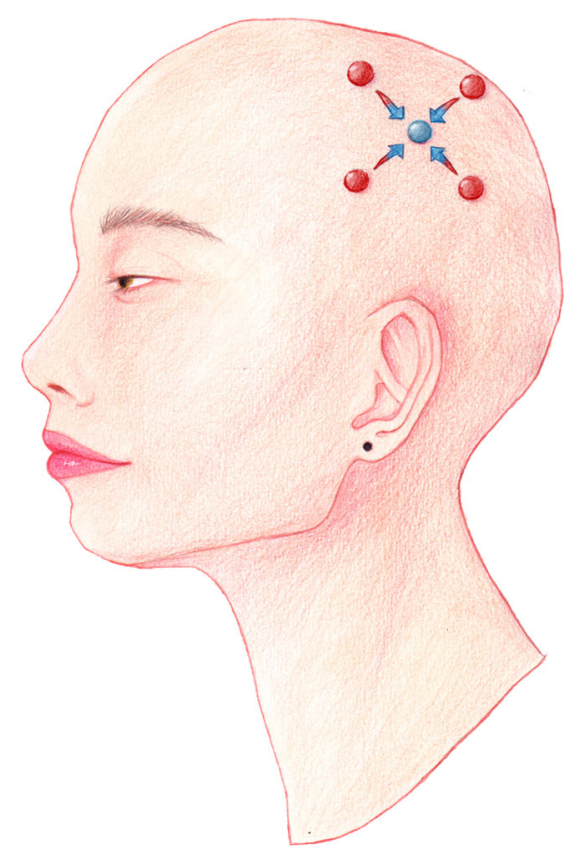

Fig. 2 Schematic representation of high-definition transcranial direct current stimulation (HD-tDCS) electrode placement. As a convention, the current flows from the anodal electrodes (presented here in red) to the cathodal electrode (blue). This picture is for illustrative purposes only

\section{Possible advantages over other neuromodulation techniques}

As the mechanisms of action of tDCS are not yet fully elucidated and it may not be considered one of the most focal noninvasive brain stimulation techniques available, why not use other more traditional and focal brain stimulation techniques? tDCS has a number of advantages when compared to other neuromodulatory techniques such as epidural direct current stimulation (EDCS), deep brain stimulation (DBS), and transcranial magnetic stimulation (TMS). tDCS is non-invasive and portable, allowing for a safe and convenient application outside the hospital environment. tDCS is inexpensive and induces rare and mild side effects. Furthermore, it allows an easy and effective sham control for clinical trials since tDCS does not produce acoustic noise or muscle twitching, and the skin sensation associated with the passage of the current can be induced by short stimulation ( $30 \mathrm{~s}$, a dosage believed to be innocuous; Gandiga et al., 2006), while the experimental stimulation extends for minutes. Furthermore, topical pretreatment with ketoprofen can reduce any possible tDCS-induced erythema (skin redness), decreasing this adverse effect and improving blinding (Guarienti et al., 2014). Also, a high stimulation frequency has to be used to induce excitatory outcomes with repetitive TMS (rTMS), and, therefore, the stimulation might induce seizures, and field standards suggest it should be delivered in hospital environments (e.g., Rossi et al., 2009). Excitatory tDCS is substantially safer and more straightforward.

It is important to note that single-pulse TMS will lead to action potentials in the stimulated area and therefore will induce a suprathreshold response. Excitatory or inhibitory repetitive TMS will lead to some interruption of the function mediated by the targeted area during the stimulation (PascualLeone, Walsh \& Rothwell, 2000). TDCS will not "interrupt" the normal brain function and can be safely and smoothly delivered during task performance. This could be considered an advantage in some cases.

The issues mentioned above support that clinical tDCS interventions outside hospital environments are feasible. In fact, there are even guidelines for this practice and commercially available devices (Charvet et al. 2015). The popularization of remotely supervised tDCS treatments might allow for a safe and effective clinical use that might be an advantage of tDCS over other neuromodulatory interventions too.

Lastly, the low focality of the standard tDCS procedure might also be considered an advantage in some cases. If for some reason a specific investigation aims at stimulating relatively large portions of the brain, tDCS (with its large electrodes) is a particularly promising technique. This might be useful in investigations of some cognitive processes that are not highly localized, for instance. 


\section{tDCS and sensory-perceptual processes}

The amount of sensory processing and rehabilitation research using tDCS today can be considered moderate when compared with the volume of research on motor system and neuropsychiatric disorders that employed this technique. The inceptive nature of this line of research is noteworthy but the successful investigations done in recent years suggest that this is a promising field and future research must be encouraged. This can be confirmed in the more specific reviews of Antal and Paulus (2008), 2011a), Zaghi et al. (2009), and Plow et al. (2012a) and in the following sections. Here we aim to present the state of the art of tDCS investigations on sensory and perceptual processing and possibilities for its use in sensory rehabilitation. Thus, as a secondary goal, we expect to inspire future research in this field. The following sections present basic research findings, followed by examples of clinical applications.

\section{Visual}

After the introduction of the contemporary tDCS procedure (Nitsche \& Paulus, 2000) one of the first sensory functions tested was visual contrast sensitivity. The tDCS montage used most frequently in this field places the active electrode over $\mathrm{Oz}$ (targeting the primary visual cortex) and the reference over $\mathrm{Cz}$ (targeting a non-visual area). Initial research in this field found grating contrast sensitivity impairments induced by cathodal tDCS (Antal et al., 2001), while anodal stimulation had no effect. Later, anodal tDCS was shown to lower phosphene thresholds while cathodal tDCS increased it (Antal et al., 2003a, b). Anodal tDCS also increased the amplitude of visual evoked potentials in response to oscillating gratings while cathodal stimulation had the opposite effect (Antal et al., 2004a). Using a motion after-effect psychophysical test, Antal et al. (2004b) showed that motion adaptation could be affected by tDCS of MT+/V5 area.

These early studies have shown that tDCS can affect visual processing with some specificity, but how specific these effects could be was not evaluated until recently. Costa et al. (2012) explored this issue by applying tDCS during a color discrimination task known to measure thresholds indicative of the parvocellular and koniocellular pathways functions (known to mediate the red-green and blue-yellow discriminations, respectively). For anodal tDCS the authors found a highly significant improvement of thresholds in the blueyellow range and no effect in the red-green range. Cathodal tDCS impaired the inferred parvocellular-driven discrimination but increased koniocellular-driven discrimination. These findings suggest that tDCS can have a relevant pathwayspecific effect over the visual cortex but whether this phenomenon was specific for color discrimination or reflected a more general trend towards differential effects of tDCS on different cell groups in the stimulated area was unclear until recently. Costa et al. (2015a) have investigated if different spatial frequency channels could be differentially affected by tDCS of the occipital pole. The authors have used psychophysical and electrophysiologic methods and observed a differential effect of tDCS on the responses to different spatial frequencies (i.e., $0.5,4.0$, and $16 \mathrm{cpd}$ ) that are known to be processed by different cell groups in the visual cortex. In agreement with these observations, this same group found differential effects of tDCS on central versus peripheral visual field thresholds (Costa et al., 2015b). These specific tDCS effects on different cell groups within the stimulated area highlight the fact that although tDCS does have a low focality in the spatial domain, its effects might be highly focal in the functional domain.

The abovementioned studies focused on hierarchically low visual functions and helped us to understand that tDCS can affect visual processing and that its effects might be surprisingly focal in the functional domain. Nonetheless, the full potential of tDCS as a tool for the study of visual processing is far from completely explored. TDCS has also shown its effects on complex perceptual tasks such as face recognition and visual search, for example.

Facial gender adaptation (when the presentation of a face will bias the gender judgment of subsequently presented faces), a complex visual illusion involving strong top-down influences, was suppressed by cathodal stimulation of the right temporo-parietal area (Varga et al., 2007). Since facial gender adaptation is known to be affected by size and retinal position of the stimulus, Varga et al. (2007) were interested in investigating if early visual retinopic areas such as V1 could be involved in this phenomenon. The stimulation of $\mathrm{V} 1 \mathrm{did}$ not affect the gender adaptation, reinforcing the fact that this illusion is determined at the level of higher order visual areas. This is an example of how tDCS can help elucidate the topdown and bottom-up mechanisms involved in visual perception. Unfortunately, this is one of the few cases of a tDCS investigation of visual illusions or face perception.

More interesting research on face perception inhibited V1 with cathodal tDCS during a task where healthy participants had to identify happy or fearful faces (backwardly masked by faces with congruent and incongruent emotions). A facilitatory effect on congruently masked stimuli was observed during sham and control conditions (Cecere et al., 2013). When tDCS inhibited V1, this effect disappeared and there was only facilitation when happy targets were masked by fearful ones. These results suggest that congruency-dependent facilitation of emotional face stimuli rely on specific activity of V1 and not only on the subcortical path (Cecere et al., 2013). It is well known that there is a specialized implicit visual processing of emotional face stimuli (as seen with blindsight in hemianopic patients or in healhy subjects for masked stimuli). Nevertheless, the extent of the involvement of cortical and sub-cortical pathways in this phenomenon is a matter of 
current debate. Coupling Cecere et al. (2013) with studies on hemianopic patients suggests that in the presence of inhibition or damage to the visual cortex, fearful faces and not happy faces are capable of eliciting a facilitation response (mostly relying on the sub-cortical pathway). Here, tDCS effects helped to shed new light on the implicit processing of emotional faces in the healthy brain and in stroke patients.

Experiments on visual search showed that tDCS may affect perceptual learning. McKinley et al. (2013) applied anodal tDCS to the F10 area (International 10-20 system) aiming at improving spatial discrimination in a simulated radar task used to train airforce officials. Subjects receiving tDCS and training achieved an improvement of visual search accuracy of approximately $25 \%$ when compared with subjects receiving training alone. This suggests that tDCS may aid perceptual learning when applied to frontal areas, an effect that is most likely explained by attention and associative learning mechanisms.

In another instance, however, anodal tDCS has been shown to interfere with perceptual learning consolidation. Peters et al. (2013) applied a visual sensitivity task in which the performance of the sham and cathodal tDCS group improved from one day to the next while the group receiving anodal tDCS did not present such improvements. The authors have delivered tDCS with the standard Oz-Cz montage in an attempt to target $\mathrm{V} 1$ and interpret these results as a possible effect of anodal tDCS on overnight visual learning consolidation (as there were no significant effects observed during the task in the first testing day). These are remarkable effects that still stand alone in the tDCS literature, as most investigations of tDCS effects on perception do not test patients on consecutive days (as there might be carryon effects between testing sessions). Nonetheless there are some studies that show that tDCS might suppress some performance increases seen when repeating a task after sham stimulation within the same session day (for examples in the visual domain see Costa et al., 2015a, for Vernier processing). This supports the notion that tDCS could suppress a normal performance improvement seen in some tasks. As the case of the Vernier processing mentioned here cannot be explained through disruption of overnight visual learning consolidation, we suggest that a cautious interpretation of the effects reported by Peters et al. (2013) and more investigations of this possible perceptual learning blocking phenomenon are advised. Nonetheless, the results mentioned in the last few paragraphs suggest that tDCS may be used in perceptual learning research.

tDCS can also be used to study hemispherical asymmetries in visual perception. Bardi et al. (2013) investigated if the lateralization of the processing of local versus global features in the posterior parietal cortex (PPC) could be explained by the relative salience of the stimuli instead of the classical local/ global dichotomy. For that purpose the authors applied anodal and cathodal tDCS to each hemisphere during a task that involved global and local selection in a context of high or low stimulus salience. Their results corroborated previous reports of right PPC attending to high salience stimuli while the left PPC is more critically involved in attending to low salience stimuli. These results also suggest that tDCS might be used as a rehabilitative tool in conditions where there is a maladaptive bias towards local or global selection in perception.

Another recent study has investigated the role of the PPC in a visual identification task with varying attentional demands and has reported interesting results. Weiss and Lavidor (2012) investigated if the decrease in excitability induced by cathodal tDCS could reduce the competition between target and background noise stimuli and lead to performance improvements in this visual identification task. The authors found significant performance improvements, a result that suggests cathodal tDCS might function as a "noise filter" in circumstances where a target has to compete for attentional resources with other elements and might end up improving performance instead of decreasing it. This hypothesis was first suggested by Antal et al. (2004b) and Antal and Paulus (2008) after observing the same cathodal tDCS effect in a random noise motion detection task. The authors suggest that as the cells processing the noise will most likely act in a more random fashion when compared with the ones processing the signal, the inhibitory effects of cathodal tDCS would be more marked over the noise and increase the signal-to-noise ratio. But regardless of the possible mechanisms behind this cathodal tDCS-driven performance boost, these results have to be kept in mind when interpreting cathodal tDCS effects on tasks where substantial noise is present. It also illustrates how tDCS outcomes might not always be straightforward.

Despite these interesting results, there are few clinical investigations of tDCS as a visual rehabilitative tool so far. Recently, tDCS was shown to be effective in improving contrast sensitivity of amblyopic patients (at least transiently). Spiegel et al. (2013) showed that eight out of 13 adult amblyopic patients had significant improvements in contrast sensitivity of the amblyopic eye after anodal tDCS (Oz-Cz montage for $15 \mathrm{~min}$ ). Also, fMRI recordings showed that the cortical activation bias towards the non-amblyopic eye was diminished after anodal stimulation. This study illustrates that this tool may help to reverse the hemispheric unbalancing of cortical activity induced by some clinical conditions. Future research could use the rationale frequently employed in motor rehabilitation research (i.e., Lindenberg et al., 2013), and take advantage of the fact that tDCS has two electrodes with different functional outcomes that may be used simultaneously to reverse this imbalance (cathode on the hyperactive and anode on the hypoactive site). Sunwoo et al. (2013) compared this approach with unilateral stimulation in ten stroke patients with unilateral visuospatial 
neglect and found the bilateral approach to be significantly more effective.

A series of studies have also shown that tDCS may be effective in treating post-stroke visual losses. In order to understand its potential to improve the visual field loss in stroke patients, a study with healthy volunteers showed that anodal tDCS over V1 could have a retinotopically-specific effect, increasing contrast sensitivity in the central visual field (Kraft et al., 2010). Later, a case study of a hemianopic patient showed that combined Visual Restoration Therapy (VRT) and anodal tDCS of V1 over 3 months led to visual field improvements equivalent to the ones expected for a 6-month treatment with VRT alone (Halko et al. 2011). The authors also showed that the changes in fMRI signal found during the treatment were significantly correlated with the modeled electric field induced by tDCS, supporting the role of tDCS as a visual rehabilitation booster.

A subsequent small sample sham-controlled study by the same group reinforced the adequacy of combining tDCS and VRT for visual field rehabilitation (Plow et al., 2011). Later, Plow et al. (2012a) investigated the effects of 3 months of combined VRT and tDCS (three times a week) in a group of eight hemianopic patients, half of whom received anodal and the other half of whom received sham tDCS. The anodal tDCS group had a significantly larger increase in visual field sensitivity and showed significant improvements in daily living vision-related activities. The improvements in daily living vision-related activities were stable after a 6-month followup. Further analyses showed that significant differences between tDCS and sham groups could already be observed after the first month of treatment, but significant shifts in visual field border could only be observed after the 3-month treatment (Plow et al. 2012b).

tDCS was also shown to improve the motion perception in a group of 12 patients with occipital ischemic lesions. Olma et al. (2013) applied anodal tDCS over the calcarine sulcus (ipsilateral to the lesion, aided by MRI-guided neuronavigation) for five consecutive days. This led to a significant improvement in motion perception that remained for at least 28 days. This suggests that tDCS effects on visual perception of stroke patients may not be limited to improvements in contrast sensitivity and visual field border.

In fact, there is new evidence suggesting that tDCS may be used for rehabilitation of other aspects of visual perception beyond contrast sensitivity and discrimination at different points in the visual field. Heth and Lavidor (2015) have found that anodal stimulation over the posterior parietal cortex improved reading fluency and speed in a group of adults diagnosed with developmental dyslexia. From a clinical point of view, these results are very relevant since there are limited treatment options for dyslexic adults. From a basic research point of view these results help to support the role of the dorsal stream in processing the orthographic input during reading and lexical processing. Nonetheless, a possible limitation has to be discussed. As the reference electrode was placed over the orbito-frontal cortex (an area that is known to be involved in many higher order cognitive processes and decision making), it is reasonable to wonder if this performance improvement might not have been influenced by the modulation of this frontal area too. Therefore, an interpretation of these effects in terms of the activity of the dorsal pathway alone might not be complete. This can be considered one case where the reference electrode placement might generate some controversy in the interpretation of results.

In summary, there are many investigations in basic and clinical research that employ tDCS to modulate visual perception and these range from very basic (e.g., contrast sensitivity) to more sophisticated functions (e.g., face perception, reading). As the neural correlates of many visual functions are better known than the ones underlying higher order cognitive functions or the ones underlying most (or all) other senses, visual perception research has also helped us to understand how specific tDCS effects are. This can be seen in the early investigations by Antal et al. (2001, 2003b, 2004a) and in the more recent works showing a high functional specificity of tDCS (Costa et al., 2012, 2015a, b). In what concerns clinical research, works like Plow et al. (2011, 2012a, b) and Sunwoo et al. (2013), have shown that tDCS can be effectively used in post-stroke rehabilitation of a sensory function (as until recently we only knew cases of tDCS use in post-stroke rehabilitation of motor functions). Taken together, the studies mentioned in this section are a robust example that $\mathrm{tDCS}$ is an adequate technique for basic visual research and a promising tool for visual rehabilitation. The stimulation parameters and outcome measures for each of the cited works are summarized in Table 2.

\section{Auditory}

In the basic research field, there are interesting examples of tDCS-induced changes of auditory processing. Zaehle et al. (2011) found that tDCS can differentially affect distinct components of the auditory-evoked potential depending on the tDCS site. Anodal stimulation over the temporal cortex increased P50 amplitudes, while cathodal stimulation of temporo-parietal areas increased N1. This result reinforces the hypothesis that different auditory areas will generate different components of the auditory evoked potential. Other authors have shown that tDCS can affect pitch detection and temporal discrimination in the auditory domain. Loui et al. (2012) showed that cathodal tDCS over the inferior frontal and superior temporal areas significantly impaired performance in a pitch-matching task, making a case for the involvement of these areas in pitch processing. Ladeira et al. (2011) applied bilateral cathodal or anodal tDCS over the temporal cortex. tDCS 
Table 2 Summary of parameters and details for each experiment study discussed in the section "Visual processing"

\begin{tabular}{|c|c|c|c|c|c|c|c|}
\hline Reference & $\begin{array}{l}\text { Location of } \\
\text { target electrode } \\
\text { (international } \\
10-20 \text { system)* }\end{array}$ & $\begin{array}{l}\text { Location } \\
\text { of return } \\
\text { electrode }\end{array}$ & $\begin{array}{l}\text { Stimulation } \\
\text { parameters }\end{array}$ & $\begin{array}{l}\text { Stimulation } \\
\text { types }\end{array}$ & $\begin{array}{l}\text { tDCS } \\
\text { protocol }\end{array}$ & $\begin{array}{l}\text { Sample size and } \\
\text { design }\end{array}$ & $\begin{array}{l}\text { Outcome measures and } \\
\text { comments }\end{array}$ \\
\hline $\begin{array}{l}\text { Antal et al. } \\
2001\end{array}$ & $\mathrm{Oz}, 35 \mathrm{~cm} \mathrm{~cm}^{2}$ & $\mathrm{Cz}, 35 \mathrm{~cm} \mathrm{~cm}^{2}$ & $\begin{array}{l}1.0 \mathrm{~mA} \text { for } \\
7 \mathrm{~min}\end{array}$ & $\begin{array}{l}\text { Anodal, } \\
\text { cathodal, } \\
\text { sham }\end{array}$ & $\begin{array}{l}\text { Online and } \\
\text { offline }\end{array}$ & $\begin{array}{l}\text { 15, within } \\
\text { participants }\end{array}$ & $\begin{array}{l}\text { Spatial and temporal } \\
\text { achromatic contrast } \\
\text { sensitivity }\end{array}$ \\
\hline $\begin{array}{l}\text { Antal et al. } \\
\text { 2003a }\end{array}$ & $\mathrm{Oz}, 35 \mathrm{~cm} \mathrm{~cm}^{2}$ & $\mathrm{Cz}, 35 \mathrm{~cm}^{2}$ & $\begin{array}{l}1.0 \mathrm{~mA} \text { for } \\
10 \mathrm{~min}\end{array}$ & $\begin{array}{l}\text { Anodal, } \\
\text { cathodal }\end{array}$ & Offline & $\begin{array}{l}\text { 16, within } \\
\text { participants }\end{array}$ & $\begin{array}{l}\text { Phosphene thresholds. } \\
\text { Phosphenes induced } \\
\text { by TMS of Oz }\end{array}$ \\
\hline $\begin{array}{l}\text { Antal et al. } \\
2003 b\end{array}$ & $\mathrm{Oz}, 35 \mathrm{~cm}^{2}$ & $\mathrm{Cz}, 35 \mathrm{~cm}^{2}$ & $\begin{array}{l}1.0 \mathrm{~mA} \text { for } \\
10 \mathrm{~min}\end{array}$ & $\begin{array}{l}\text { Anodal, } \\
\text { cathodal }\end{array}$ & Offline & $\begin{array}{l}\text { Nine, within } \\
\text { participants }\end{array}$ & $\begin{array}{l}\text { Moving phosphene } \\
\text { thresholds. Moving } \\
\text { phosphenes induced } \\
\text { by TMS of V5 }\end{array}$ \\
\hline $\begin{array}{l}\text { Antal et al. } \\
2004 \mathrm{a}\end{array}$ & Oz, O1 $35 \mathrm{~cm}^{2}$ & $\mathrm{Cz}, \mathrm{O} 2,35 \mathrm{~cm}^{2}$ & $\begin{array}{l}1.0 \mathrm{~mA} \text { for } 5 \\
\text { or } 15 \mathrm{~min}\end{array}$ & $\begin{array}{l}\text { Anodal, } \\
\text { cathodal }\end{array}$ & Offline & $\begin{array}{l}\text { 10, within } \\
\text { participants }\end{array}$ & $\begin{array}{l}\text { Amplitudes and latencies } \\
\text { or visual evoked } \\
\text { potential for achromatic } \\
\text { sine-wave gratings }\end{array}$ \\
\hline $\begin{array}{l}\text { Antal et al. } \\
2004 b\end{array}$ & $* \mathrm{Oz}, \mathrm{V} 5,35 \mathrm{~cm}^{2}$ & $\mathrm{Cz}, 35 \mathrm{~cm}^{2}$ & $\begin{array}{l}1.0 \mathrm{~mA} \text { for } \\
15 \mathrm{~min}\end{array}$ & $\begin{array}{l}\text { Anodal, } \\
\text { Cathodal, } \\
\text { sham }\end{array}$ & Offline & $\begin{array}{l}\text { 12, within } \\
\text { participants }\end{array}$ & $\begin{array}{l}\text { Motion adaptation induced } \\
\text { by coherently moving } \\
\text { dots }\end{array}$ \\
\hline $\begin{array}{l}\text { Bardi et al. } \\
\quad 2013\end{array}$ & $\begin{array}{l}\text { Bilateral PPC } \\
\quad(\mathrm{P} 3, \mathrm{P} 4) \\
9 \mathrm{~cm}^{2}\end{array}$ & No & $\begin{array}{l}1.5 \mathrm{~mA} \text { for } \\
20 \mathrm{~min}\end{array}$ & $\begin{array}{l}\text { Anodal, } \\
\text { cathodal, } \\
\text { sham }\end{array}$ & Online & $\begin{array}{l}\text { Nin9, within } \\
\text { participants }\end{array}$ & $\begin{array}{l}\text { Navon letters global-local } \\
\text { task with low and high } \\
\text { salience stimuli }\end{array}$ \\
\hline $\begin{array}{l}\text { Cecere et al. } \\
2013\end{array}$ & $01,35 \mathrm{~cm}^{2}$ & $\mathrm{Cz}, 35 \mathrm{~cm}^{2}$ & $\begin{array}{l}2.0 \mathrm{~mA} \text { for } \\
15 \mathrm{~min}\end{array}$ & $\begin{array}{l}\text { Cathodal, } \\
\text { sham }\end{array}$ & Offline & $\begin{array}{l}\text { 26, between } \\
\text { participants }\end{array}$ & $\begin{array}{l}\text { Happy or fearful faces } \\
\text { (backwardly masked by } \\
\text { faces with congruent } \\
\text { and incongruent facial } \\
\text { emotions) }\end{array}$ \\
\hline $\begin{array}{l}\text { Costa et al. } \\
2012\end{array}$ & $\mathrm{Oz}, 25 \mathrm{~cm}^{2}$ & $\mathrm{Cz}, 25 \mathrm{~cm}^{2}$ & $\begin{array}{l}1.5 \mathrm{~mA} \text { for } \\
20 \mathrm{~min}\end{array}$ & $\begin{array}{l}\text { Anodal, } \\
\text { cathodal, } \\
\text { sham }\end{array}$ & Online & $\begin{array}{l}\text { 15, within } \\
\text { participants }\end{array}$ & $\begin{array}{l}\text { Color discri mination } \\
\text { thresholds in protan, } \\
\text { deutan, and tritan } \\
\text { confusion axes. Red- } \\
\text { green grating threshold }\end{array}$ \\
\hline $\begin{array}{c}\text { Costa et al. } \\
2015 \mathrm{a}\end{array}$ & $\mathrm{Oz}, 25 \mathrm{~cm}^{2}$ & $\mathrm{Cz}, 25 \mathrm{~cm}^{2}$ & $\begin{array}{l}1.5 \mathrm{~mA} \text { for } \\
\sim 30 \mathrm{~min}\end{array}$ & $\begin{array}{l}\text { Anodal, } \\
\text { cathodal, } \\
\text { sham }\end{array}$ & $\begin{array}{l}\text { Online and } \\
\text { offline }\end{array}$ & $\begin{array}{l}\text { 17, within } \\
\text { participants }\end{array}$ & $\begin{array}{l}\text { Psychophysical and VEP } \\
\text { for achromatic contrast } \\
\text { sensitivity (sine wave } \\
\text { gratings) ON and OFF } \\
\text { lu minance thresholds } \\
\text { Vernier Acuity }\end{array}$ \\
\hline $\begin{array}{l}\text { Costa et al. } \\
2015 b\end{array}$ & $\mathrm{Oz}, 25 \mathrm{~cm}^{2}$ & $\mathrm{Cz}, 25 \mathrm{~cm}^{2}$ & $\begin{array}{l}1.5 \mathrm{~mA} \text { for } \\
20 \mathrm{~min}\end{array}$ & $\begin{array}{l}\text { Anodal, } \\
\text { cathodal, } \\
\text { sham }\end{array}$ & Offline & $\begin{array}{l}\text { 15, within } \\
\text { participants }\end{array}$ & $\begin{array}{l}\text { Central }(10-2) \text { and } \\
\text { peripheral }(60-4) \\
\text { automated threshold } \\
\text { perimetry }\end{array}$ \\
\hline $\begin{array}{l}\text { Costa et al. } \\
2015 \mathrm{c}\end{array}$ & $\mathrm{Oz}, 25 \mathrm{~cm}^{2}$ & $\mathrm{Cz}, 25 \mathrm{~cm}^{2}$ & $\begin{array}{l}1.5 \mathrm{~mA} \text { for } \\
\sim 20 \mathrm{~min}\end{array}$ & $\begin{array}{l}\text { Anodal, } \\
\text { cathodal, } \\
\text { sham }\end{array}$ & Online & $\begin{array}{l}\text { 14, within } \\
\text { participants }\end{array}$ & $\begin{array}{l}\text { Size and distance scaling } \\
\text { task }\end{array}$ \\
\hline $\begin{array}{l}\text { Halko et al. } \\
\quad 2011\end{array}$ & $\mathrm{Oz}, 35 \mathrm{~cm}^{2}$ & $\mathrm{Cz}, 35 \mathrm{~cm}^{2}$ & $\begin{array}{l}2.0 \mathrm{~mA} \text { for } \\
30 \mathrm{~min}\end{array}$ & Anodal & Online & Case study & $\begin{array}{l}\text { Hemianopic patient } \\
\text { underwent } 36 \text { sessions } \\
\text { (over } 3 \text { months) of tDCS } \\
\text { coupled with visual } \\
\text { rehabilitation training. } \\
\text { Outcomes evaluated } \\
\text { with behavioral results } \\
\text { and fMRI }\end{array}$ \\
\hline $\begin{array}{l}\text { Heth \& Lavidor } \\
\quad 2015\end{array}$ & $\begin{array}{l}* \text { Left V5, } \\
25 \mathrm{~cm}^{2}\end{array}$ & $\begin{array}{l}\text { Right orbitofrontal, } \\
35 \mathrm{~cm}^{2}\end{array}$ & $\begin{array}{l}1.5 \mathrm{~mA} \text { for } \\
20 \mathrm{~min} \text { (five } \\
\text { sessions) }\end{array}$ & Anodal, sham & Offline & $\begin{array}{l}\text { 19, clinical, } \\
\text { between } \\
\text { participants }\end{array}$ & $\begin{array}{l}\text { Adult dyslexia tested in } \\
\text { number of reading and } \\
\text { naming tasks }\end{array}$ \\
\hline $\begin{array}{l}\text { Kraft et al. } \\
\quad 2010\end{array}$ & $\begin{array}{l}\mathrm{O} 1 \text { or } \mathrm{O} 2 \\
25 \mathrm{~cm}^{2}\end{array}$ & $\mathrm{Cz}, 70 \mathrm{~cm}^{2}$ & $\begin{array}{l}1.0 \mathrm{~mA} \text { for } \\
15 \mathrm{~min}\end{array}$ & $\begin{array}{l}\text { Anodal, } \\
\text { cathodal, } \\
\text { sham }\end{array}$ & Offline & $\begin{array}{l}\text { 12, within } \\
\text { participants }\end{array}$ & $\begin{array}{l}\text { Central }(10-2) \text { automated } \\
\text { threshold perimetry }\end{array}$ \\
\hline $\begin{array}{l}\text { Mckinley et al. } \\
2013\end{array}$ & $\mathrm{~F} 10,5 \times 1.6 \mathrm{~cm}$ & $\begin{array}{l}\text { Extracephalic, } \\
5 \times 1.6 \mathrm{~cm}\end{array}$ & $\begin{array}{l}2.0 \mathrm{~mA} \text { for } \\
30 \mathrm{~min}\end{array}$ & Anodal, sham & Online & $\begin{array}{l}\text { 27, between } \\
\text { participants }\end{array}$ & $\begin{array}{l}\text { Visual search task used in } \\
\text { air force education }\end{array}$ \\
\hline
\end{tabular}


Table 2 (continued)

\begin{tabular}{|c|c|c|c|c|c|c|c|}
\hline Reference & $\begin{array}{l}\text { Location of } \\
\text { target electrode } \\
\text { (international } \\
10-20 \text { system)* }\end{array}$ & $\begin{array}{l}\text { Location } \\
\text { of return } \\
\text { electrode }\end{array}$ & $\begin{array}{l}\text { Stimulation } \\
\text { parameters }\end{array}$ & $\begin{array}{l}\text { Stimulation } \\
\text { types }\end{array}$ & $\begin{array}{l}\text { tDCS } \\
\text { protocol }\end{array}$ & $\begin{array}{l}\text { Sample size and } \\
\text { design }\end{array}$ & $\begin{array}{l}\text { Outcome measures and } \\
\text { comments }\end{array}$ \\
\hline $\begin{array}{l}\text { Olma et al. } \\
2013\end{array}$ & $\begin{array}{l}* \text { MRI-derived } \\
\text { V1, } 25 \mathrm{~cm}^{2}\end{array}$ & $\mathrm{Cz}, 35 \mathrm{~cm}^{2}$ & $\begin{array}{l}1.5 \mathrm{~mA} \text { for } \\
20 \mathrm{~min}(5 \\
\text { consecutive } \\
\text { days })\end{array}$ & Anodal, sham & Offline & $\begin{array}{l}\text { 12, clinical, } \\
\text { within } \\
\text { participants }\end{array}$ & $\begin{array}{l}\text { Stroke patients with } \\
\text { occipital lesions tested } \\
\text { with a campimetric } \\
\text { motion detection task }\end{array}$ \\
\hline $\begin{array}{l}\text { Peters et al. } \\
2013\end{array}$ & $\mathrm{Oz}, 35 \mathrm{~cm}^{2}$ & $\mathrm{Cz}, 35 \mathrm{~cm}^{2}$ & $\begin{array}{l}1.0 \mathrm{~mA} \text { for } \\
20 \mathrm{~min}\end{array}$ & $\begin{array}{l}\text { Anodal, } \\
\text { cathodal, } \\
\text { sham }\end{array}$ & Online & $\begin{array}{l}\text { 24, between } \\
\text { participants }\end{array}$ & $\begin{array}{l}\text { An achromatic contrast } \\
\text { discrimination task that } \\
\text { presents a learning } \\
\text { effect after consecutive } \\
\text { stimulation days }\end{array}$ \\
\hline $\begin{array}{l}\text { Plow et al. } \\
\quad 2011\end{array}$ & $\mathrm{Oz}, 35 \mathrm{~cm}^{2}$ & $\mathrm{Cz}, 35 \mathrm{~cm}^{2}$ & $\begin{array}{l}2.0 \mathrm{~mA} \text { for } \\
30 \mathrm{~min}\end{array}$ & Anodal, sham & Online & $\begin{array}{l}\text { Two, clinical, } \\
\text { between } \\
\text { participants }\end{array}$ & $\begin{array}{l}\text { Hemianopic patients } \\
\text { underwent } 4 \text { sessions a } \\
\text { week (over } 3 \text { months) } \\
\text { of tDCS coupled with a } \\
\text { visual rehabilitation } \\
\text { training. Outcomes } \\
\text { evaluated with } \\
\text { behavioral results and } \\
\text { fMRI }\end{array}$ \\
\hline $\begin{array}{l}\text { Plow et al. } \\
2012 \mathrm{a}\end{array}$ & $\mathrm{Oz}, 35 \mathrm{~cm}^{2}$ & $\mathrm{Cz}, 35 \mathrm{~cm}^{2}$ & $\begin{array}{l}2.0 \mathrm{~mA} \text { for } \\
30 \mathrm{~min} \\
\text { (twice a day) }\end{array}$ & Anodal, sham & Online & $\begin{array}{l}\text { Eight, clinical, } \\
\text { between } \\
\text { participants }\end{array}$ & $\begin{array}{l}\text { Hemianopic patients } \\
\text { underwent } 3 \text { sessions a } \\
\text { week (over } 3 \text { months) } \\
\text { of tDCS coupled with a } \\
\text { visual rehabilitation } \\
\text { training. Outcomes } \\
\text { evaluated with } \\
\text { behavioral results } \\
\text { (Visual field increase) }\end{array}$ \\
\hline $\begin{array}{l}\text { Plow et al. } \\
2012 b\end{array}$ & $\mathrm{Oz}, 35 \mathrm{~cm}^{2}$ & $\mathrm{Cz}, 35 \mathrm{~cm}^{2}$ & $\begin{array}{l}2.0 \mathrm{~mA} \text { for } \\
30 \mathrm{~min} \\
\text { (twice a day) }\end{array}$ & Anodal, sham & Online & $\begin{array}{l}\text { 12, clinical, } \\
\text { between } \\
\text { participants }\end{array}$ & $\begin{array}{l}\text { Hemianopic patients } \\
\text { underwent } 3 \text { sessions a } \\
\text { week (over } 3 \text { months) } \\
\text { of tDCS coupled with a } \\
\text { visual rehabilitation } \\
\text { training. Outcomes } \\
\text { evaluated with high } \\
\text { resolution perimetry }\end{array}$ \\
\hline $\begin{array}{l}\text { Spiegel et al. } \\
2013\end{array}$ & $\mathrm{Oz}, 43 \mathrm{~cm}^{2}$ & $\mathrm{Cz}, 109 \mathrm{~cm}^{2}$ & $\begin{array}{l}2.0 \mathrm{~mA} \text { for } \\
15 \mathrm{~min}\end{array}$ & $\begin{array}{l}\text { Anodal, } \\
\text { cathodal, } \\
\text { sham }\end{array}$ & $\begin{array}{l}\text { Online and } \\
\text { offline }\end{array}$ & $\begin{array}{l}\text { 13, within } \\
\text { participants }\end{array}$ & $\begin{array}{l}\text { Amblyopic patients tested } \\
\text { for contrast sensitivity } \\
\text { with achromatic Gabors } \\
\text { (psychophysics) and } \\
\text { achromatic gratings } \\
\text { (fMRI) }\end{array}$ \\
\hline $\begin{array}{l}\text { Sunwoo et al. } \\
2013\end{array}$ & $\begin{array}{c}\text { Bilateral PPC } \\
\text { (P3-P4) or } \\
\text { P4, } 25 \mathrm{~cm}^{2}\end{array}$ & $\begin{array}{l}\text { Contralateral } \\
\text { supraorbital, } \\
25 \mathrm{~cm}^{2}\end{array}$ & $\begin{array}{l}1.0 \mathrm{~mA} \text { for } \\
20 \mathrm{~min}\end{array}$ & $\begin{array}{l}\text { Anodal, } \\
\text { cathodal, } \\
\text { sham }\end{array}$ & Offline & $\begin{array}{l}\text { 10, clinical, } \\
\text { within } \\
\text { participants }\end{array}$ & $\begin{array}{l}\text { Stroke patients with } \\
\text { unilateral spatial } \\
\text { neglect tested with a } \\
\text { line bisection task } \\
\text { and star cancelation } \\
\text { task }\end{array}$ \\
\hline $\begin{array}{l}\text { Varga et al. } \\
2007\end{array}$ & $\begin{array}{c}\mathrm{Oz}, \mathrm{P} 6-\mathrm{P} 8 \\
35 \mathrm{~cm}^{2}\end{array}$ & $\mathrm{Cz}, 35 \mathrm{~cm}^{2}$ & $\begin{array}{c}1.0 \mathrm{~mA} \text { for } \\
10 \mathrm{~min}\end{array}$ & $\begin{array}{l}\text { Anodal, } \\
\text { cathodal, } \\
\text { sham }\end{array}$ & Online & $\begin{array}{l}\text { 17, between } \\
\text { participants }\end{array}$ & $\begin{array}{l}\text { Facial gender adaptation } \\
\text { task }\end{array}$ \\
\hline $\begin{array}{l}\text { Weiss and } \\
\text { Lavidor } \\
2012\end{array}$ & $\mathrm{P} 4,16 \mathrm{~cm}^{2}$ & $\begin{array}{l}\text { Contralateral } \\
\text { supraorbital, } \\
35 \mathrm{~cm}^{2}\end{array}$ & $\begin{array}{l}1.5 \mathrm{~mA} \text { for } \\
15 \mathrm{~min}\end{array}$ & $\begin{array}{l}\text { Anodal, } \\
\text { cathodal, } \\
\text { sham }\end{array}$ & Online & $\begin{array}{l}\text { 50, between } \\
\text { participants }\end{array}$ & $\begin{array}{l}\text { An attentional load } \\
\text { paradigm where } \\
\text { participants have to } \\
\text { find a target letter alone } \\
\text { or in the middle of few } \\
\text { confounders }\end{array}$ \\
\hline
\end{tabular}

Studies in alphabetical order

*Asterisks mark the studies that do not employ the International 10-20 electrode placement system. Whenever an electrode was placed between two 10-20 coordinates, these coordinates are connected by a "_." (e.g., F3-FP1) 
was more effective over high frequencies (specifically $4 \mathrm{KHz}$ ), with a polarity specific effect in a temporal resolution task. An average $22.5 \%$ improvement in performance by anodal and $54.5 \%$ decrease in performance by cathodal tDCS were found. Frequencies from 500 to $2000 \mathrm{~Hz}$ were not affected by tDCS, showing a frequencydependent effect of tDCS.

The role of the frontal cortex in auditory perception and attention is a fertile research field. A recent study used tDCS and auditory mismatch negativity (MMN, an electrophysiologic signature of change detection) to discuss this issue. Chen et al. (2014a) recorded MMN to both duration and frequency (pitch) of auditory stimuli after tDCS of the right inferior frontal cortex. Anodal tDCS was found to significantly decrease MMN for frequency while tDCS had no effect on MMN for duration of stimuli. These results helped clarifying the differential role of the right inferior frontal cortex on the perception of frequency and duration changes on auditory stimuli. Also, it supports the idea that different networks underlie the perception of frequency and duration changes (Chen et al., 2014a). A compatible result was found by Impey and Knott (2015), who observed MMN increases after anodal stimulation of the left auditory cortex. Impey and Knott have also observed another relevant result. The MMN modulation was more intense in participants who had lower baseline MMN amplitudes, a fact that highlights the relevance of understanding individual baselines as a variable that might influence tDCS outcomes.

As we have mentioned before, tDCS has a significant potential as a tool in the study of hemispheric asymmetries and cortical organization, and the work of Heimrath et al. (2014) is a compelling example of that. There are numerous reports suggesting the left auditory cortex is specialized for speech processing while the right auditory cortex specializes in the prosodic and emotional content of speech (reviewed in Scott \& McGettigan, 2013). Recently, some authors discuss if this specialization can be accounted for by lower level processing, i.e., a left specialization for temporal resolution and a right specialization for spectral resolution (e.g., Heimrath et al., 2014; Zatorre \& Belin, 2001). Nonetheless, the complexity of this issue and the presence of contrasting results (like the ones showing reversed hemispheric specialization of auditory processing) in the literature leaves this hypothesis unresolved (Scott \& McGettigan, 2013). It is important to emphasize that most research on this issue rely on models or correlational methods and does not involve direct brain stimulation techniques.

In order to address this controversy, Heimrath et al. (2014) used a gap detection task (a standard task to measure auditory temporal resolution) and tDCS to discuss the cortical asymmetries in sampling time and temporal resolution. The authors found that stimulation over the left but not the right auditory cortex significantly decreased accuracy in a temporal resolution task. These results help strengthen the left auditory cortex specialization for temporal stimuli. Nonetheless, the anodal effect observed here is an inhibitory one. The authors suggest that since they used a healthy young sample, the auditory cortex function was at a resource ceiling and the specified function had a fine-tuning that was mainly distressed by this artificial modulation (as seen for Vernier processing in Costa et al., 2015a, for instance).

In the field of clinical tDCS research on the auditory system, most studies investigate tinnitus, a condition associated with synchronized hyperactivity in the auditory cortex (Langguth et al. 2008). In order to modulate this activity, Fregni et al. (2006a) delivered $1 \mathrm{~mA}$ tDCS or $5 \mathrm{~Hz}$ repetitive transcranial magnetic stimulation (rTMS) to the left temporoparietal area (LTA) of seven chronic tinnitus patients. Anodal tDCS leads to a significant suppression of tinnitus similar to that induced by rTMS (Fregni et al. 2006a). Although the tDCS-induced tinnitus suppression was short lasting, these results encouraged further explorations of those effects and so far this is the most common application of tDCS on clinical research of auditory functions.

Accordingly, some authors have explored how different tDCS parameters and other factors can lead to stronger and longer lasting tinnitus suppression. Garin et al. (2011) replicated the research of Fregni et al. (2006a) on a bigger sample $(\mathrm{N}=20)$. Anodal tDCS had a significant effect in tinnitus suppression and interestingly, half the patients declared longer lasting effects, some lasting more than 2 weeks after the tDCS session. These aftereffects varied and some participants even reported pitch changes in tinnitus (Garin et al. 2011). Shekhawat et al. (2013) explored the effect of different tDCS intensities (1-2 mA) and durations (10-20 min) in tinnitus suppression. Anodal LTA stimulation with $2 \mathrm{~mA}$ for 20 min was shown to be the more effective parameter, leading to transient tinnitus suppression in $56 \%$ of participants and long-lasting (overnight) relief in the rest of the sample.

Surprisingly, although combining tDCS and behavioral training seems to be a promising rehabilitation approach (as shown in previous sections), no significant effects were found by Teismann et al. (2014) in tinnitus patients. The authors combined tailor-made notched music training (a treatment that consists of listening to music tracks with the dominant tinnitus frequency filtered out) and tDCS of the left auditory cortex for ten consecutive days in a group of tinnitus patients. Although the treatment was shown to be effective (also in a 30-day follow up), no differences were found between anodal, cathodal, and sham tDCS. Possibly different electrode montages might help to elucidate these effects. More specifically, tDCS of the DLPFC could be an effective alternative. Accordingly, Faber et al. (2012) showed that bilateral tDCS of the DLPFC induced a decrease in the annoyance of tinnitus. Later, Vanneste et al. (2013) showed that bilateral DLPFC stimulation significantly modulated both the 
annoyance and the loudness of the tinnitus. These are examples of how tDCS of non-sensory areas might have a useful outcome to sensory rehabilitation.

It is important to note that $\mathrm{tDCS}$ has been shown to induce alleviation of auditory hallucinations in schizophrenic patients. Brunelin et al. (2012) applied sham or $2 \mathrm{~mA}$ cathodal tDCS over the left temporo-parietal cortex with simultaneous anodal stimulation over the left DLPFC twice a day for five consecutive days in a sample of 30 schizophrenic patients with medication-refractory auditory hallucinations. A significant reduction of auditory hallucinations (average reduction of $31 \%$ ) was found and lasted for up to 3 months. Negative symptom amelioration was also observed. A case study by Andrade (2013) corroborated these findings. A patient with severe medical-refractory continuous auditory hallucinations received 1-3 mA tDCS with the same montage as Brunelin et al. (2012) for 3 years. Improvements were observed after 1 week and a 90 $\%$ self-reported decrease in frequency of auditory hallucinations was achieved after the second treatment month. The patient improved from a psychosocial vegetative state to nearnormal functioning, but the benefits attenuated whenever session frequency decreased. This is why tDCS sessions were maintained for 3 years (Andrade, 2013). A more recent case study by Nawani et al. (2014) replicated these findings and supports the use of tDCS in the treatment of auditory hallucinations. Another case study, with a pregnant patient (a case where tDCS might be particularly appropriate as many antipsychotic medications are considered teratogenic while there are no significant contraindications for tDCS), has observed a significant decrease in auditory hallucinations after 5 days of auditory cortex tDCS (Shenoy et al., 2015).

In spite of the positive results in these four studies, Fitzgerald et al. (2014) have found that uni- or bilateral tDCS over the same sites targeted in Brunelin et al. (2012) had no effects over auditory hallucinations or negative symptoms in a sample of schizophrenia patients. Parametric issues might explain the different results between Brunelin et al. and Fitzgerald et al.: tDCS was applied twice a day in the Brunelin et al. study and only once a day by the Fitzgerald group. These different outcomes highlight how dosage is a critical issue in tDCS research and how more parametric studies are needed to better understand the optimal stimulation parameters for both clinical populations and basic research.

As is the case of visual processing research, auditory perception research using tDCS is still in its infancy. In the field of basic research, many relevant results have been found so far and the tool has been shown to be useful in broadening our understanding of the cortical organization of auditory functions (e.g., Heimrath et al., 2014) and the generators of auditory evoked potential (Zaehle et al., 2011). Research in this field has also helped us to understand that participants with different baseline performances might be affected differently by tDCS (Impey \& Knott 2015). In the field of clinical research, tDCS was mostly used to treat tinnitus and auditory hallucinations with promising results. In sum, the results presented in this section support that tDCS is a relevant new technique in auditory perception research. The stimulation parameters and outcome measures for each of the cited works are summarized in Table 3.

\section{Somatosensory}

Somatosensory perception is one of the sensory systems most frequently studied using tDCS and research in this field continues to grow. Within this topic we discuss tDCS effects on somatosensory functions excluding pain research (which is discussed in the next section). The electrode montage that seems to be the most popular here places the active electrode over primary somatosensory cortex $(\mathrm{S} 1)$ and the reference electrode at the contralateral supraorbital area. One of the first studies adopting this configuration showed that tactile discrimination of vibratory stimuli was disrupted during and after $1 \mathrm{~mA}$ cathodal tDCS over S1 while no anodal effects were observed (Rogalewski et al., 2004). These findings were corroborated by electrophysiologic evidence that showed significantly reduced somatosensory evoked potentials (SEP) when cathodal tDCS was applied over S1 (Dieckhöfer et al., 2006).

Modulation of somatosensory processing was also possible through stimulation of the motor cortex. Matsunaga et al. (2004) showed that $1 \mathrm{~mA}$ anodal tDCS over the left M1 area increased the amplitude of somatosensory-evoked potentials for up to $60 \mathrm{~min}$ after the end of stimulation (no cathodal effects reported). Later, Ragert et al. (2008) showed that anodal tDCS of S1 significantly improved tactile discrimination in a grating orientation task for up to 40 min after the end of stimulation. The differences in anodal effects between Rogalewski et al. (2004) and Ragert et al. (2008) might be explained by the different tDCS parameters used. The presence of an anodal effect was obtained by a higher current density applied for a longer duration: while the earlier study used $0.028 \mathrm{~mA} / \mathrm{cm}^{2}$ over $7 \mathrm{~min}$, the later work used $0.04 \mathrm{~mA} /$ $\mathrm{cm}^{2}$ over $20 \mathrm{~min}$ of stimulation. These results reinforce the need for parametric studies in the future.

The initial psychophysical demonstration that tDCS had an effect on tactile discrimination was followed by further studies that explored tDCS effects on thermal and pressure perception. Cold detection and mechanical detection thresholds were increased by cathodal tDCS of M1, while anodal tDCS had no effect (Bachmann et al., 2010). Also, effects of the stimulation of the left S1 on thermal perception were found, with cathodal tDCS increasing cold detection thresholds in both hands and warm detection thresholds in the contralateral hand only (Grundmann et al., 2011).

tDCS was also used to investigate the role of the cerebellum in somatosensory perception, a critical issue in current research of somatosensory processing. Chen et al. (2014b) 
Table 3 Summary of parameters for the experimental studies discussed in the section "Auditory processing"

\begin{tabular}{|c|c|c|c|c|c|c|c|}
\hline Reference & $\begin{array}{l}\text { Location of target } \\
\text { electrode } \\
\text { (international } \\
10-20 \text { system) }\end{array}$ & $\begin{array}{l}\text { Location of return } \\
\text { electrode }\end{array}$ & $\begin{array}{l}\text { Stimulation } \\
\text { parameters }\end{array}$ & $\begin{array}{l}\text { Stimulation } \\
\text { types }\end{array}$ & $\begin{array}{l}\text { tDCS } \\
\text { protocol }\end{array}$ & $\begin{array}{l}\text { Sample size and } \\
\text { design }\end{array}$ & $\begin{array}{l}\text { Outcome measures and } \\
\text { comments }\end{array}$ \\
\hline Andrade 2013 & T3-P3, $25 \mathrm{~cm}^{2}$ & $\mathrm{~F} 3,25 \mathrm{~cm}^{2}$ & $\begin{array}{l}\text { From } 1.0 \text { to } \\
3.0 \mathrm{~mA} \text { for } \\
20-30 \mathrm{~min}\end{array}$ & Active & Offline & Case study & $\begin{array}{l}\text { Severity of auditory } \\
\text { hallucinations in } \\
\text { schizophrenia after } \\
\text { once or twice daily } \\
\text { tDCS sessions for } 3 \\
\text { years }\end{array}$ \\
\hline $\begin{array}{l}\text { Brunelin et al. } \\
2012\end{array}$ & $\mathrm{~F} 3-\mathrm{FP} 1,35 \mathrm{~cm}^{2}$ & $\mathrm{~T} 3-\mathrm{P} 3,35 \mathrm{~cm}^{2}$ & $\begin{array}{l}2.0 \mathrm{~mA} \text { for } \\
20 \mathrm{~min}\end{array}$ & $\begin{array}{l}\text { Active and } \\
\text { Sham }\end{array}$ & Offline & $\begin{array}{l}50 \text { (24 for tDCS), } \\
\text { Clinical trial }\end{array}$ & $\begin{array}{l}\text { Severity of auditory } \\
\text { hallucinations in } \\
\text { schizophrenia after } \\
\text { two tDCS sessions a } \\
\text { day for } 5 \text { consecutive } \\
\text { days }\end{array}$ \\
\hline $\begin{array}{l}\text { Chen et al. } \\
2014 \mathrm{a}\end{array}$ & $\mathrm{F} 4,35 \mathrm{~cm}^{2}$ & $\begin{array}{l}\text { Contralateral } \\
\text { supraorbital, } \\
35 \mathrm{~cm}^{2}\end{array}$ & $\begin{array}{l}2.0 \mathrm{~mA} \text { for } \\
20 \mathrm{~min}\end{array}$ & $\begin{array}{l}\text { Anodal, } \\
\text { cathodal, } \\
\text { sham }\end{array}$ & Offline & $\begin{array}{l}\text { 10, within } \\
\text { participants }\end{array}$ & $\begin{array}{c}\text { Auditory mismatch } \\
\text { negativity event } \\
\text { related potential }\end{array}$ \\
\hline $\begin{array}{l}\text { Faber et al. } \\
2012\end{array}$ & $\mathrm{~T} 4,35 \mathrm{~cm}^{2}$ & $\mathrm{~T} 3,35 \mathrm{~cm}^{2}$ & $\begin{array}{l}1.5 \mathrm{~mA} \text { for } \\
20 \mathrm{~min}\end{array}$ & $\begin{array}{l}\text { Active and } \\
\text { sham }\end{array}$ & Offline & $\begin{array}{l}\text { 15, clinical, } \\
\text { within } \\
\text { participants }\end{array}$ & $\begin{array}{l}\text { Tinnitus patients. } \\
\text { Intensity of change in } \\
\text { Tinnitus symptoms } \\
\text { evaluated after } 6 \text { days } \\
\text { of tDCS }\end{array}$ \\
\hline $\begin{array}{l}\text { Fitzgerald et al. } \\
2014\end{array}$ & $\mathrm{~F} 3$ or $\mathrm{F} 4,35 \mathrm{~cm}^{2}$ & $\begin{array}{l}\text { TP3 or TP4, } \\
35 \mathrm{~cm}^{2}\end{array}$ & $\begin{array}{l}2.0 \mathrm{~mA} \text { for } \\
20 \mathrm{~min}\end{array}$ & Active, sham & Offline & $\begin{array}{l}\text { 24, clinical, } \\
\text { between } \\
\text { participants }\end{array}$ & $\begin{array}{l}\text { Severity of auditory } \\
\text { hallucinations in } \\
\text { schizophrenia after } \\
\text { tDCS once a day for } \\
5 \text { days }\end{array}$ \\
\hline $\begin{array}{l}\text { Fregni et al. } \\
2006 \mathrm{a}\end{array}$ & $\mathrm{C} 3,35 \mathrm{~cm}^{2}$ & $\begin{array}{l}\text { Contralateral } \\
\text { supraorbital, } \\
35 \mathrm{~cm}^{2}\end{array}$ & $\begin{array}{l}1.0 \mathrm{~mA} \text {, Two } \\
\text { subsequent } \\
3 \text { min sessions }\end{array}$ & $\begin{array}{l}\text { Anodal, } \\
\text { cathodal, } \\
\text { sham }\end{array}$ & Offline & $\begin{array}{l}\text { Seven, clinical, } \\
\text { within } \\
\text { participants }\end{array}$ & $\begin{array}{l}\text { Tinnitus patients. } \\
\text { Intensity of Tinnitus } \\
\text { symptoms evaluated } \\
\text { before and after } \\
\text { tDCS }\end{array}$ \\
\hline $\begin{array}{l}\text { Garin et al. } \\
2011\end{array}$ & $\mathrm{C} 3-\mathrm{T} 5,35 \mathrm{~cm}^{2}$ & $\mathrm{~T} 4-\mathrm{F} 8,50 \mathrm{~cm}^{2}$ & $\begin{array}{l}1.0 \mathrm{~mA} \text { for } \\
20 \mathrm{~min}\end{array}$ & $\begin{array}{l}\text { Anodal, } \\
\text { cathodal, } \\
\text { sham }\end{array}$ & Offline & $\begin{array}{l}\text { 20, clinical, } \\
\text { within } \\
\text { participants }\end{array}$ & $\begin{array}{l}\text { Tinnitus patients. } \\
\text { Intensity of change in } \\
\text { Tinnitus symptoms } \\
\text { evaluated after tDCS } \\
\text { and a 2-week follow up }\end{array}$ \\
\hline $\begin{array}{l}\text { Heimrath et al. } \\
2014\end{array}$ & $\mathrm{~T} 7, \mathrm{~T} 8,25 \mathrm{~cm}^{2}$ & $\mathrm{C} 4-\mathrm{C} 3,50 \mathrm{~cm}^{2}$ & $\begin{array}{l}1.25 \mathrm{~mA}, \\
\text { unspecified } \\
\text { duration }\end{array}$ & Anodal, sham & Online & $\begin{array}{l}\text { 15, within } \\
\text { participants }\end{array}$ & $\begin{array}{l}\text { Auditory gap detection } \\
\text { task }\end{array}$ \\
\hline $\begin{array}{l}\text { Impey and } \\
\text { Knott, } 2015\end{array}$ & $\begin{array}{l}\text { C5-T7, unspecified } \\
\text { size }\end{array}$ & $\begin{array}{l}\text { Contralateral } \\
\text { supraorbital, } \\
\text { unspecified size }\end{array}$ & $\begin{array}{l}2.0 \mathrm{~mA} \text { for } \\
20 \mathrm{~min}\end{array}$ & Anodal, sham & Offline & $\begin{array}{l}\text { 12, within } \\
\text { participants }\end{array}$ & $\begin{array}{l}\text { Auditory mismatch } \\
\text { negativity event } \\
\text { related potential }\end{array}$ \\
\hline $\begin{array}{l}\text { Ladeira et al. } \\
\quad 2011\end{array}$ & $\begin{array}{l}\text { Simultaneous T3 } \\
\text { and } \mathrm{T} 4,35 \mathrm{~cm}^{2}\end{array}$ & $\begin{array}{l}\text { Contralateral } \\
\text { deltoid, } \\
35 \mathrm{~cm}^{2}\end{array}$ & $\begin{array}{c}2.0 \mathrm{~mA} \text { for } \\
10 \mathrm{~min}\end{array}$ & $\begin{array}{l}\text { Anodal, } \\
\text { cathodal, } \\
\text { sham }\end{array}$ & Online & $\begin{array}{l}\text { 11, within } \\
\text { participants }\end{array}$ & $\begin{array}{l}\text { Auditory random gap } \\
\text { detection task. This } \\
\text { experiment used } \\
\text { bi-hemispheric tDCS } \\
\text { with the same electrode } \\
\text { polarity in each } \\
\text { hemisphere }\end{array}$ \\
\hline $\begin{array}{l}\text { Loui et al. } \\
\quad 2012\end{array}$ & $\begin{array}{l}\text { TP7-C5, TP8-C6, } \\
\text { F7-C5, F8-C6, } \\
16 \mathrm{~cm}^{2}\end{array}$ & $\begin{array}{l}\text { Contralateral } \\
\text { supraorbital, } \\
16 \mathrm{~cm}^{2}\end{array}$ & $\begin{array}{l}2.0 \mathrm{~mA} \text { for } \\
20 \mathrm{~min}\end{array}$ & $\begin{array}{l}\text { Cathodal, } \\
\text { sham }\end{array}$ & Offline & $\begin{array}{l}\text { Nine, within } \\
\text { participants }\end{array}$ & Pitch matching task \\
\hline $\begin{array}{l}\text { Nawani et al. } \\
2014\end{array}$ & T3-P3, $35 \mathrm{~cm}^{2}$ & $\mathrm{~F} 3-\mathrm{FP} 1,35 \mathrm{~cm}^{2}$ & $\begin{array}{l}2.0 \mathrm{~mA} \text { for } \\
20 \mathrm{~min}\end{array}$ & Active & Offline & Case study & $\begin{array}{l}\text { Auditory evoked potential } \\
\text { (Speech stimuli) in } \\
\text { schizophrenia after two } \\
\text { tDCS sessions a day for } \\
5 \text { days }\end{array}$ \\
\hline
\end{tabular}


Table 3 (continued)

\begin{tabular}{|c|c|c|c|c|c|c|c|}
\hline Reference & $\begin{array}{l}\text { Location of target } \\
\text { electrode } \\
\text { (international } \\
10-20 \text { system) }\end{array}$ & $\begin{array}{l}\text { Location of return } \\
\text { electrode }\end{array}$ & $\begin{array}{l}\text { Stimulation } \\
\text { parameters }\end{array}$ & $\begin{array}{l}\text { Stimulation } \\
\text { types }\end{array}$ & $\begin{array}{l}\text { tDCS } \\
\text { protocol }\end{array}$ & $\begin{array}{l}\text { Sample size and } \\
\text { design }\end{array}$ & $\begin{array}{l}\text { Outcome measures and } \\
\text { comments }\end{array}$ \\
\hline $\begin{array}{l}\text { Shekhawat et al. } \\
2013\end{array}$ & $\mathrm{C} 3-\mathrm{T} 5,35 \mathrm{~cm}^{2}$ & $\mathrm{~T} 4-\mathrm{F} 8,50 \mathrm{~cm}^{2}$ & $\begin{array}{l}1.0 \text { or } 2.0 \mathrm{~mA} \\
\text { for } 10 \text { or } \\
20 \mathrm{~min}\end{array}$ & Anodal & Offline & $\begin{array}{l}\text { 25, clinical, } \\
\text { within } \\
\text { participants }\end{array}$ & $\begin{array}{l}\text { Tinnitus patients. } \\
\text { Intensity of change in } \\
\text { Tinnitus symptoms } \\
\text { evaluated after tDCS }\end{array}$ \\
\hline $\begin{array}{l}\text { Shenoy et al. } \\
2015\end{array}$ & T3-P3, $35 \mathrm{~cm}^{2}$ & $\mathrm{~F} 3-\mathrm{FP} 1,35 \mathrm{~cm}^{2}$ & $\begin{array}{l}2.0 \mathrm{~mA} \text { for } \\
20 \mathrm{~min}\end{array}$ & Active & Offline & Case study & $\begin{array}{l}\text { Severity of auditory } \\
\text { hallucinations in a } \\
\text { pregnant schizophrenia } \\
\text { patient after twice } \\
\text { daily tDCS sessions } \\
\text { for } 5 \text { days }\end{array}$ \\
\hline $\begin{array}{l}\text { Teismann et al. } \\
2014\end{array}$ & $\mathrm{C} 3-\mathrm{T} 3,35 \mathrm{~cm}^{2}$ & $\begin{array}{l}\text { Contralateral } \\
\text { supraorbital, } \\
100 \mathrm{~cm}^{2}\end{array}$ & $\begin{array}{l}2.0 \mathrm{~mA} \text { for } \\
30 \mathrm{~min}\end{array}$ & $\begin{array}{l}\text { Anodal, } \\
\text { cathodal, } \\
\text { sham }\end{array}$ & Offline & $\begin{array}{l}\text { 32, clinical, } \\
\text { between } \\
\text { participants }\end{array}$ & $\begin{array}{l}\text { Tinnitus patients. } \\
\text { Intensity of change } \\
\text { in Tinnitus symptoms } \\
\text { evaluated after } 5 \text { days } \\
\text { of tDCS coupled with a } \\
\text { music-training task }\end{array}$ \\
\hline $\begin{array}{l}\text { Vanneste et al. } \\
2013\end{array}$ & $\mathrm{~F} 3,35 \mathrm{~cm}^{2}$ & $\mathrm{~F} 4,35 \mathrm{~cm}^{2}$ & $\begin{array}{l}2.0 \mathrm{~mA} \text { for } \\
20 \mathrm{~min}\end{array}$ & $\begin{array}{l}\text { Active and } \\
\text { Sham }\end{array}$ & Offline & $\begin{array}{l}\text { 50, clinical, } \\
\text { between } \\
\text { participants }\end{array}$ & $\begin{array}{l}\text { Tinnitus patients. Intensity } \\
\text { of change in Tinnitus } \\
\text { symptoms evaluated } \\
\text { tDCS. Results compared } \\
\text { with tACS }\end{array}$ \\
\hline $\begin{array}{l}\text { Zaehle et al. } \\
\quad 2011\end{array}$ & $\begin{array}{l}\mathrm{T} 7 \text { or } \mathrm{CP} 5 \\
35 \mathrm{~cm}^{2}\end{array}$ & $\begin{array}{l}\text { Contralateral } \\
\text { supraorbital, } \\
35 \mathrm{~cm}^{2}\end{array}$ & $\begin{array}{l}1.25 \mathrm{~mA} \text { for } \\
11 \mathrm{~min}\end{array}$ & $\begin{array}{l}\text { Anodal, } \\
\text { cathodal, } \\
\text { sham }\end{array}$ & Offline & $\begin{array}{l}\text { 14, within } \\
\text { participants }\end{array}$ & $\begin{array}{l}\text { Auditory Evoked } \\
\text { Potentials }\end{array}$ \\
\hline
\end{tabular}

Studies in alphabetical order

*Asterisks mark the studies that do not employ the International 10-20 electrode placement system. Whenever an electrode was placed between two 1020 coordinates, these coordinates are connected by a “_“ (e.g., F3-FP1)

measured the vibratory somatosensory mismatch negativity (MMN, an electrophysiologic measure of change detection) before and after tDCS of the right cerebellar hemisphere. The authors found that while somatosensory MMN was affected by both anodal and cathodal tDCS, the auditory MMN was not affected by tDCS. This shows a relevant link between cerebellar activity and somatosensory MMN (complementing previous research with pharmacologic interventions) and is a compelling example of tDCS potential in aiding investigations of cerebellar function (Chen et al., 2014b).

A recent finding of somatosensory perception research deserves to be highlighted here. It is well known that the visual cortex may be recruited by tactile stimulation in blind and sensory-deprived subjects. It is also known that in certain circumstances tactile information may entrain visual and auditory areas in healthy subjects, leading to the hypothesis that this crossmodal process could be a typical characteristic of sensory processing and not a consequence of deprivation (see Ghazanfar \& Schroeder, 2006). Yau et al. (2014) investigated this hypothesis by applying tDCS to the auditory or visual cortices during tactile discrimination tasks of spatial orientation and temporal frequency. The authors observed a significant improvement in tactile spatial orientation perception during tDCS of the visual but not auditory cortex. Also, tDCS of the auditory but not visual cortex improved tactile temporal frequency perception. These results shed light over the role of different pathways for spatial and temporal information within the somatosensory system. This also helps reinforce the idea that in some cases, sensory cortical areas process sensory information from different input modalities and that thinking of cortical function in terms of supramodal domains (like spatial information or temporal information) may be appropriate. This is a clear example of how tDCS may be a useful tool to study multimodal integration. More on this topic will be presented in the last section.

Although still not commonly applied, the use of dualhemisphere tDCS (with anodal and cathodal tDCS simultaneously placed in homologous areas at the two hemispheres) is also showing promising results in the research of somatosensory processes. Fujimoto et al. (2013) compared dual and uni-hemisphere tDCS on the right index finger performance in a tactile spatial discrimination task. In the dual- hemisphere condition, anodal tDCS over the left and cathodal tDCS over the right S1 area were simultaneously applied. The uni- 
hemisphere condition applied anodal tDCS to the left S1 and cathodal to the contralateral supraorbital area. The authors found a significantly higher percentage of correct responses for the dual-hemisphere condition when compared to the unihemisphere one. Taken together with the abovementioned studies, this finding supports the potential clinical application of tDCS in somatosensory rehabilitation.

The improvement of somatosensory perception is clinically relevant for a number of reasons: different clinical conditions might impair somatosensory perception affecting quality of life, reductions of somatosensory input impair motor control (Monzée et al. 2003), and increases in somatosensory input improve motor function (Kaelin-Lang et al. 2002). However, research with clinical populations is still lacking, and most of the investigations focus on pain alleviation (as presented in the next section). The study by Mori et al. (2013) with multiple sclerosis showed promising results. Twenty multiple sclerosis patients were divided into in two groups and received $20 \mathrm{~min}$ tDCS of S1 over five consecutive days. Half the participants received anodal tDCS and the other half received sham stimulation. tDCS significantly improved grating orientation thresholds and visual analogue sensation scores for up to 2 weeks after the end of stimulation but did not affect quality-of-life measures. A more recent study has focused on the fatigue symptoms experienced by multiple sclerosis patients. Tecchio et al. (2014) delivered bilateral S1 anodal tDCS through individualized electrodes designed to fit the primary somatosensory cortical strip. The study found significant reduction of fatigue symptoms in all patients tested. These results highlights that tDCS is a promising tool for treatment of very specific symptoms in multiple sclerosis and that individualized electrodes might be a tool to achieve more substantial outcomes.

In summary, this section has showed a number of studies where tDCS helped to improve our understanding of somatosensory perception. The stimulation parameters and outcome measures for each of the cited works are summarized in Table 4. It is important to note that this is one very promising technique to discuss the role of the cerebellum in somatosensory perception, as discussed by Chen et al. (2014b). The fact that some sensory areas might process information regardless of the input modality (i.e., in supramodal domains like temporal information for instance) was observed by Yau et al. (2014) by applying tDCS over the somatosensory cortex of healthy adults. These results helped us to understand that the entrainment of the somatosensory cortex by visual or auditory information is not a peculiarity of the blind or sensory-deprived and are helping to unveil possible supermodel processing mechanisms in human cognition. In the clinical research field, few investigations used tDCS to treat for tactile or thermal somatosensory processing. Nonetheless, many investigations have found promising results in treating acute or chronic pain, as we review below.

\section{Pain}

Among the body of research on tDCS effects over sensory/ perceptual functions, the field of pain research seems to be the one where this technique is more broadly and frequently employed. A Pubmed search for the keywords "tDCS" and "Pain" retrieved 182 results at the time of preparing this review. So far, tDCS induced significant alleviation of pain symptoms in a number of clinical conditions such as neuropathic pain (Kim et al 2013; Zaghi et al., 2009), Fibromyalgia (Fregni et al., 2006b; Valle et al., 2009), postsurgical pain (Borckardt et al., 2013), multiple sclerosis (Mori et al., 2010), and migraine (Antal et al., 2011b). tDCS was also shown to modulate experimentally-induced pain sensation both in healthy volunteers and in patients (reviewed by Mylius et al., 2012).

In a systematic review, Zaghi et al. (2009) concluded that when compared to other neuromodulatory techniques (such as repetitive TMS or EDCS), tDCS is the most cost-effective treatment for central pain (considering treatments shorter than 5 years). Also, 5 days of tDCS tend to induce a greater relief of pain symptoms than 5 days of repetitive TMS (Plow et al. 2012c). Nonetheless, it is important to note that a recent Cochrane Database Systematic Review has found that there is still insufficient evidence for the use of non-pharmacologic interventions (i.e., tDCS, TMS, exercise programs, acupuncture, and others) in the treatment of neuropathic chronic pain, at least in spinal cord-injured patients (Boldt et al. 2011). It is also important to note that the conclusion in Boldt et al. (2011) is not that these interventions are ineffectual, but that more research with randomized control protocols, adequate sample sizes, and sensitive methods to evaluate outcomes are needed. We fully agree with these conclusions and would like to suggest the same for each of the specific research fields reviewed here. In fact, a more detailed discussion of this issue will be presented in the next section ("How can our understanding of tDCS profit from more perception and psychophysics research?") and in the concluding remarks.

In what concerns electrode placements in pain tDCS and TMS research, the primary motor cortex is the most frequently targeted area (Mylius et al., 2012). There are numerous examples were anodal tDCS over M1 induced decreases in pain perception. Fregni et al. (2006c) reported significant pain relief improvements after the delivery of $20 \mathrm{~min}$ of anodal tDCS over M1 for five consecutive days in a sample of patients with spinal cord injury. Fregni et al. (2006c) also found that this tDCS protocol induced pain relief in a sample of fibromyalgia patients for up to 3 weeks after the end of the stimulation.

Among the studies delivering tDCS over M1 to modulate pain sensation is one of the few examples of high-definition tDCS (HD-tDCS) use on a sensory/perceptual function so far. Borckardt et al. (2012) delivered $2 \mathrm{~mA}$ anodal HD-tDCS over 
Table 4 Summary of parameters for the experimental studies discussed in the section "Somatosensory perception"

\begin{tabular}{|c|c|c|c|c|c|c|c|}
\hline Reference & $\begin{array}{l}\text { Location of target } \\
\text { electrode } \\
\text { (international } \\
10-20 \text { system)* }\end{array}$ & $\begin{array}{l}\text { Location of } \\
\text { return electrode }\end{array}$ & $\begin{array}{l}\text { Stimulation } \\
\text { parameters }\end{array}$ & $\begin{array}{l}\text { Stimulation } \\
\text { types }\end{array}$ & $\begin{array}{l}\text { tDCS } \\
\text { protocol }\end{array}$ & $\begin{array}{l}\text { Sample size and } \\
\text { design }\end{array}$ & $\begin{array}{l}\text { Outcome measures and } \\
\text { comments }\end{array}$ \\
\hline $\begin{array}{l}\text { Bachmann } \\
\text { et al. } 2010\end{array}$ & $\begin{array}{l}\text { C3, Unspecified } \\
\text { size }\end{array}$ & $\begin{array}{l}\text { Contralateral } \\
\text { supraorbital, } \\
\text { Unspecified } \\
\text { size }\end{array}$ & $\begin{array}{l}1.0 \mathrm{~mA} \text { for } \\
15 \mathrm{~min}\end{array}$ & $\begin{array}{l}\text { Anodal, } \\
\text { cathodal } \\
\text { sham }\end{array}$ & Offline & $\begin{array}{l}\text { Eight, within } \\
\text { participants }\end{array}$ & $\begin{array}{l}\text { Thermal, mechanical } \\
\text { detection and pain } \\
\text { threshold estimation } \\
\text { tasks }\end{array}$ \\
\hline $\begin{array}{l}\text { Chen et al. } \\
2014 b\end{array}$ & $\begin{array}{l}\text { *Right cerebellum, } \\
25 \mathrm{~cm}^{2}\end{array}$ & $\begin{array}{l}\text { Buccanitor muscle, } \\
25 \mathrm{~cm}^{2}\end{array}$ & $\begin{array}{l}2.0 \mathrm{~mA} \text { for } \\
25 \mathrm{~min}\end{array}$ & $\begin{array}{l}\text { Anodal, } \\
\text { cathodal, } \\
\text { sham }\end{array}$ & Offline & $\begin{array}{l}\text { 10, within } \\
\text { participants }\end{array}$ & $\begin{array}{l}\text { Auditory and } \\
\text { somatosensory } \\
\text { mismatch negativity } \\
\text { event related potential }\end{array}$ \\
\hline $\begin{array}{l}\text { Dieckhöfer } \\
\text { et al. } 2006\end{array}$ & $\begin{array}{l}* \text { Parietal site } \\
24 \mathrm{~cm}^{2}\end{array}$ & $\begin{array}{l}\text { Contralateral } \\
\text { forehead, } \\
24 \mathrm{~cm}^{2}\end{array}$ & $\begin{array}{l}1.0 \mathrm{~mA} \text { for } \\
9 \mathrm{~min}\end{array}$ & $\begin{array}{l}\text { Anodal, } \\
\text { cathodal, } \\
\text { sham }\end{array}$ & Offline & $\begin{array}{l}\text { 10, within } \\
\text { participants }\end{array}$ & $\begin{array}{l}\text { Median nerve } \\
\text { somatosensory evoked } \\
\text { potential }\end{array}$ \\
\hline $\begin{array}{l}\text { Fujimoto } \\
\text { et al. } 2013\end{array}$ & $\begin{array}{l}\text { *Bilateral and } \\
\text { unilateral } \mathrm{S} 1 \\
\text { (MRI derived), } \\
25 \mathrm{~cm}^{2}\end{array}$ & $\begin{array}{l}\text { Contralateral } \\
\text { supraorbital, } \\
25 \mathrm{~cm}^{2}\end{array}$ & $\begin{array}{l}1.0 \mathrm{~mA} \text { for } \\
20 \mathrm{~min}\end{array}$ & $\begin{array}{l}\text { Anodal, } \\
\text { cathodal, } \\
\text { sham }\end{array}$ & $\begin{array}{l}\text { Online and } \\
\text { offline }\end{array}$ & $\begin{array}{l}\text { Nine, within } \\
\text { participants }\end{array}$ & $\begin{array}{l}\text { Tactile discrimination } \\
\text { task (grating } \\
\text { orientation) }\end{array}$ \\
\hline $\begin{array}{l}\text { Grundmann } \\
\text { et al. } 2011\end{array}$ & $\begin{array}{l}\text { C3, Unspecified } \\
\text { size }\end{array}$ & $\begin{array}{l}\text { Contralateral } \\
\text { supraorbital, } \\
\text { Unspecified } \\
\text { size }\end{array}$ & $\begin{array}{l}1.0 \mathrm{~mA} \text { for } \\
15 \mathrm{~min}\end{array}$ & $\begin{array}{l}\text { Anodal, } \\
\text { cathodal } \\
\text { sham }\end{array}$ & Offline & $\begin{array}{l}\text { 12, within } \\
\text { participants }\end{array}$ & $\begin{array}{l}\text { Thermal, mechanical } \\
\text { detection and pain } \\
\text { threshold estimation } \\
\text { tasks }\end{array}$ \\
\hline $\begin{array}{l}\text { Matsunaga } \\
\text { et al. } 2004\end{array}$ & $\begin{array}{l}\text { * Right Abductor } \\
\text { Brevis M1 (TMS } \\
\text { confirmed), } \\
35 \mathrm{~cm}^{2}\end{array}$ & $\begin{array}{l}\text { Contralateral } \\
\text { supraorbital, } \\
35 \mathrm{~cm}^{2}\end{array}$ & $\begin{array}{l}1.0 \mathrm{~mA} \text { for } \\
10 \mathrm{~min}\end{array}$ & $\begin{array}{l}\text { Anodal, } \\
\text { cathodal }\end{array}$ & Offline & $\begin{array}{l}\text { Eight, within } \\
\text { participants }\end{array}$ & $\begin{array}{l}\text { Median nerve } \\
\text { somatosensory evoked } \\
\text { potential }\end{array}$ \\
\hline $\begin{array}{l}\text { Mori et al. } \\
2013\end{array}$ & $\mathrm{C} 3, \mathrm{C} 4,35 \mathrm{~cm}^{2}$ & $\begin{array}{l}\text { Contralateral } \\
\text { supraorbital, } \\
35 \mathrm{~cm}^{2}\end{array}$ & $\begin{array}{l}2.0 \mathrm{~mA} \text { for } \\
20 \mathrm{~min}\end{array}$ & Anodal, sham & Offline & $\begin{array}{l}\text { 20, clinical, } \\
\text { within } \\
\text { participants }\end{array}$ & $\begin{array}{l}\text { Multiple sclerosis patients } \\
\text { tested in a tactile } \\
\text { discrimination task } \\
\text { (grating orientation) } \\
\text { and quality of life } \\
\text { measures after } 5 \\
\text { consecutive days of } \\
\text { tDCS }\end{array}$ \\
\hline $\begin{array}{l}\text { Ragert et al. } \\
\quad 2008\end{array}$ & $\mathrm{C} 3,25 \mathrm{~cm}^{2}$ & $\begin{array}{l}\text { Contralateral } \\
\text { supraorbital, } \\
25 \mathrm{~cm}^{2}\end{array}$ & $\begin{array}{l}1.0 \mathrm{~mA} \text { for } \\
20 \mathrm{~min}\end{array}$ & Anodal, sham & $\begin{array}{l}\text { Online and } \\
\text { offline }\end{array}$ & $\begin{array}{l}\text { 10, within } \\
\text { participants }\end{array}$ & $\begin{array}{l}\text { Tactile discrimination } \\
\text { task (grating } \\
\text { orientation) }\end{array}$ \\
\hline $\begin{array}{l}\text { Rogalewski } \\
\text { et al. } 2004\end{array}$ & $\mathrm{C} 4,35 \mathrm{~cm}^{2}$ & $\begin{array}{l}\text { Contralateral } \\
\text { supraorbital, } \\
35 \mathrm{~cm}^{2}\end{array}$ & $\begin{array}{l}1.0 \mathrm{~mA} \text { for } \\
7 \mathrm{~min}\end{array}$ & $\begin{array}{l}\text { Anodal, } \\
\text { cathodal, } \\
\text { sham }\end{array}$ & $\begin{array}{l}\text { Online and } \\
\text { offline }\end{array}$ & $\begin{array}{l}\text { 13, within } \\
\text { participants }\end{array}$ & $\begin{array}{l}\text { Tactile frequency } \\
\text { discrimination task }\end{array}$ \\
\hline $\begin{array}{l}\text { Tecchio et al. } \\
2014\end{array}$ & $\begin{array}{l}\text { *Personalized } \\
\text { somatosensory } \\
\text { strip shaped } \\
\text { (MRI derived), } \\
25 \mathrm{~cm}^{2}\end{array}$ & $\mathrm{Oz}, 70 \mathrm{~cm}^{2}$ & $\begin{array}{l}1.5 \mathrm{~mA} \text { for } \\
15 \mathrm{~min}\end{array}$ & Anodal, sham & Offline & $\begin{array}{l}\text { 10, clinical, } \\
\text { within } \\
\text { participants }\end{array}$ & $\begin{array}{l}\text { Fatigue scales and } \\
\text { quality-of-life } \\
\text { measures after } 5 \\
\text { consecutive days of } \\
\text { tDCS }\end{array}$ \\
\hline $\begin{array}{c}\text { Yau et al. } \\
2014\end{array}$ & $\mathrm{Oz}, \mathrm{T} 3,25 \mathrm{~cm}^{2}$ & $\begin{array}{l}\text { Buccanitor muscle, } \\
25 \mathrm{~cm}^{2}\end{array}$ & $\begin{array}{l}1.0 \text { or } 2.0 \mathrm{~mA} \\
\text { for } 20 \mathrm{~min}\end{array}$ & Anodal, sham & $\begin{array}{l}\text { Online and } \\
\text { offline }\end{array}$ & $\begin{array}{l}\text { 15, within } \\
\text { participants }\end{array}$ & $\begin{array}{l}\text { Tactile spatial acuity } \\
\text { (grating orientation) } \\
\text { and tactile frequency } \\
\text { discrimination task } \\
\text { (vibratory stimuli) }\end{array}$ \\
\hline
\end{tabular}

Studies in alphabetical order

*Asterisks mark the studies that do not employ the International 10-20 electrode placement system. Whenever an electrode was placed between two 1020 coordinates, these coordinates are connected by a “_“ (e.g., F3-FP1)

the motor cortex of healthy volunteers. This induced an analgesic effect on thermal wind-up pain and cold pain thresholds. These results suggest that HD-tDCS is an effective technique for modulation of sensory/perceptual functions and future investigations in the field should take advantage of this higher stimulation focality. 
tDCS over the DLPFC was also shown to be effective in pain modulation. In a sample of healthy volunteers, Boggio et al. (2008) showed that anodal tDCS over DLPFC induced increases in pain thresholds similar to the increase induced by stimulation of M1. Valle et al. (2009) found that ten sessions of $2 \mathrm{~mA}$ tDCS over M1 or DLPFC induced a reduction in pain scores of fibromyalgia patients. On the other hand, only the group receiving tDCS over M1 still presented pain reduction after a 30-day follow up. It was also shown that anodal tDCS over DLPFC significantly decreased the ratings of unpleasantness, discomfort, and pain in response to a set of aversive images with similar valence (Boggio et al. 2009a). These results are in accordance with the notion of the DLPFC as a center for the processing of emotional components of pain, also suggesting that tDCS over DLPFC might be successfully employed to modulate the emotional aspect of pain in clinical cases.

A recent tDCS study has promoted significant advances in our understanding of pain processing mechanisms and must be highlighted here. Bocci et al. (2015) have stimulated the cerebellum in a sample of healthy participants in order to understand its role in the pain processing matrix. These authors have found that cerebellar tDCS was able to modulate pain thresholds in a polarity-dependent manner, a result that has helped to link the cerebellum to pain processing. In addition to that, both anodal and cathodal stimulation have modulated different components (N1 and N2/P2) of laser evoked potentials (an electrophysiologic technique where somatosensory stimulation is performed by transient lasers applied to the hand, for instance). These effects on both components of the laser-evoked potentials suggest that not only is the cerebellum related to pain processing, but it might be involved in a processing matrix that involves both the somatosensory and cingulated cortices (see Bocci et al., 2015 for a discussion). These results also suggest that pain treatments might profit from using cerebellar tDCS and not only somatosensory or motor cortex tDCS.

In the field of pain rehabilitation, the combination of tDCS with other therapeutic interventions is a promising approach. Anodal M1 tDCS combined with TENS (transcutaneous electrical nerve stimulation) of the upper limbs resulted in significantly stronger pain reduction than tDCS or TENS alone in a sample of eight patients with neurogenic arm pain (Boggio et al., 2009b). Riberto et al. (2011) tested the effect of combining tDCS ( $2 \mathrm{~mA}$ once a week for 10 weeks) with a multidisciplinary rehabilitation program (ergonomic education, stretching, occupational therapy, group psychotherapy, and more) in a sample of 23 fibromyalgia patients. Combining therapy and tDCS led to a significant improvement in quality-of-life scores and a marginally significant improvement in the Fibromyalgia Impact Questionnaire $(p=0.056)$ when compared to therapy alone. More recently, Schabrun et al. (2014) showed that coupling tDCS and peripheral electrical stimulation to treat chronic low back pain was significantly effective in reducing pain, sensitization (as measured for pressure pain thresholds), and also normalizing motor cortex organization (i.e., reversing the plastic changes that are known to take place in the motor cortex as a result of chronic pain) as measured by TMS-induced motor-evoked potentials.

An interesting therapeutic effect was also observed by Bolognini et al. (2013) on amputee patients. In a first experiment, patients received anodal and sham tDCS over M1. In a second experiment they received anodal, cathodal, and sham tDCS over the posterior parietal cortex (PPC, $0.057 \mathrm{~mA} / \mathrm{cm}^{2}$, $15 \mathrm{~min}$ ). After the tDCS sessions, patients were evaluated with regard to phantom limb and stump pain, phantom sensation, and telescoping. They found a decrease in phantom pain immediately after anodal M1 tDCS. Also, phantom sensations where decreased immediately after cathodal PPC tDCS. tDCS was once again able to dissociate the functional relation between different cortical areas and the perceptual processes involved. Although both M1 and PPC suffer similar plastic reorganizations following limb amputations, these areas seem to have different roles on the phantom limb perception.

The combination of tDCS and visual illusion-based interventions for pain treatment in patients with spinal cord injury is another promising area of investigation. Soler et al. (2010) combined anodal tDCS of M1 with a visual illusion described by Moseley (2007), where the patient is seated in the wheelchair facing a video projection that gives the impression of walking over a treadmill. Thirty-nine patients received ten sessions over two consecutive weeks. The group receiving tDCS associated with the illusion had significant pain score decreases when compared to groups that received sham tDCS or either tDCS or illusion alone. These comparisons were still significant at 12 weeks after the end of treatment (Soler et al., 2010). Later, Kumru et al. (2013) examined the effects of the interventions proposed by Soler et al. (2010) on psychophysical heat and pain thresholds and contact heat-evoked potentials (CHEP). The authors found a significant reduction in heat/pain thresholds and CHEP amplitude after combined visual illusion and tDCS. This intervention led to a normalization of heat and pain thresholds in the dermatomes rostral to the injury level (Kumru et al. 2013).

tDCS-induced analgesia might also be used to diminish the amount of analgesic delivered after surgery and other medical procedures. Twenty minutes of anodal tDCS over the left prefrontal cortex after an endoscopy procedure led to a significant decrease in pain sensation and pain interference in sleep (Borckardt et al., 2011). The participants that received real tDCS required $22 \%$ less analgesic medication than the sham tDCS group. In a later study, Borckardt et al. (2013) showed that patients who received 80 min of tDCS after total knee arthroplasty surgery required approximately half of the analgesic dosage of the group receiving sham 
tDCS. In an effort to target the knee representation area in the motor cortex, the anodal electrode was positioned over $\mathrm{C} 1$ or $\mathrm{C} 2$ in the 10-20 system and the cathode over the right DLPF C. The study of Borckardt et al. (2013) shows very promising results but it is important to keep in mind that since 16 $\mathrm{cm}^{2}$ were used, a large portion of the motor cortex was stimulated and not only a knee representation area. Therefore, these results might be interpreted as analgesic effects induced by widespread modulation of the motor cortex induced by tDCS.

Lastly, an interesting approach to pain treatment is to modulate the cognitive aspects of the painful experience. An analgesic effect of anodal tDCS over the left DLPFC on fibromyalgia patients, attributed to the modulation of the emotional components of pain, has been reported by Valle et al. (2009). Anodal tDCS $\left(0.125 \mathrm{~mA} / \mathrm{cm}^{2}\right)$ delivered to the left DLPFC of 41 subjects resulted in lower pain unpleasantness ratings, while cathodal tDCS had the opposite effects (Naylor et al., 2013). This is in agreement with previous findings (for instance, Boggio et al., 2009a, Valle et al. 2009), but probably the most exciting finding is that tDCS affected the perception of control over the pain sensation. In one of the tasks in the study by Naylor et al. (2013), subjects were led to believe that their responses in a behavioral task prior to the CHEPS stimulation could lead to a decrease in stimulation intensity. In a questionnaire presented after the experiments, subjects reported that they had felt more control over the painful stimulation after anodal tDCS and less control after cathodal tDCS.

Interestingly, in a meta-analysis of the effects of different tDCS montages on pain of patient groups, the pain relieving effect of anodal tDCS on DLPFC was bigger than for M1 (Vaseghi et al., 2014). It is important to note that when compared to tDCS of M1, the number of investigations of pain modulation by DLPFC stimulation is still very limited. It is also important to note that it is hard to ascertain which are the factors behind pain alleviation of the perception of increased control over the painful sensation in works like Naylor et al. (2013). Maybe there is a modulation of pain perception by divided attention mechanisms. Or maybe there is a role of mood changes, as has been shown in many studies to stimulate the DLPFC. Nevertheless, this opens an avenue for new studies of tDCS-induced analgesia targeting higher-order cognitive processes and frontal cortical areas.

In summary, tDCS may affect pain processing in a number of clinically relevant ways, but its potential as a therapeutic tool is only starting to be investigated. In the field of basic research, we have also presented a number of studies that have employed tDCS to unveil the pain processing networks in the human brain. We highlight here the ones that are helping us to understand the role of frontal brain areas (reviewed by Vaseghi et al., 2014) and the cerebellum (Bocci et al., 2015) in pain processing. Taken together, the results presented here support the notion that $\mathrm{tDCS}$ is a promising technique for pain rehabilitation and for the study of pain processing. The stimulation parameters and outcome measures for each of the cited studies are summarized in Table 5.

\section{Olfactory and gustatory}

Although some clinical conditions lead to olfactory and gustatory sensitivity losses that impair quality of life, we are not aware of any studies that have used tDCS to modulate these functions. Considering the role of these senses in a well adapted and fulfilling life, together with the number of open questions in what concerns olfactory and gustatory processing, employing tDCS in future investigations of these functions is highly advised.

\section{Multimodal integration}

When studying perception, each sensory modality is often seen independently. However, most external events and objects stimulate different sensory modalities simultaneously, thus their integration is necessary (Macaluso \& Driver, 2005). Consequently, the understanding of how multimodal stimuli are integrated and even how each specific modality can affect crossmodal perception is extremely relevant.

A group in Italy pioneered the multisensory integration research testing tDCS effects over the posterior parietal cortex (Bolognini et al., 2010a, b). There was a general increase of spatial orientation in healthy subjects tested before and after tDCS over the right posterior parietal cortex (PPC) in a redundant signal effect task, using audio, video, and audiovisual stimuli. Specifically, anodal tDCS was able to enhance orientation to contralateral stimuli, modulating the processing of both modality-specific and multimodal stimuli (Bolognini et al., 2010a). Also concerning spatial attention, Bolognini et al. (2010b) explored the effect of anodal PPC tDCS on a visual field exploration training aided by auditory cues. Stimulation of the right PPC (but not the left) induced significant improvement in visual exploration. The results from this line of research suggest that tDCS may be a promising tool to improve performance in tasks that require multisensory visuospatial and visuomotor integration.

It is noteworthy that tDCS findings demonstrated the PPC involvement in those specific tasks and, although considered an associative area, it seems not to be crucial in other tasks integrating audiovisual information. Specifically, tDCS of the PPC showed no significant effects over the sound-induced flash illusion; where simultaneous presentation of one visual flash and two auditory beeps results in a fission-illusion, i.e., perception of two flashes. The fusion-illusion, i.e., perception of one flash, is produced by the simultaneous presentation of two visual flashes and one audio beep (Shams et al., 2000). Since both auditory and visual stimuli are presented together, the brain appears to interpret it as arising from the same 
Table 5 Summary of parameters and results for the studies discussed in the section "Pain"

\begin{tabular}{|c|c|c|c|c|c|c|c|}
\hline Reference & $\begin{array}{l}\text { Location of } \\
\text { target electrode } \\
\text { (international } \\
10-20 \text { system)* }\end{array}$ & $\begin{array}{l}\text { Location of } \\
\text { return electrode }\end{array}$ & Stimulation parameters & $\begin{array}{l}\text { Stimulation } \\
\text { types }\end{array}$ & $\begin{array}{l}\text { tDCS } \\
\text { protocol }\end{array}$ & $\begin{array}{l}\text { Sample size and } \\
\text { design }\end{array}$ & $\begin{array}{l}\text { Outcome measures and } \\
\text { comments }\end{array}$ \\
\hline $\begin{array}{l}\text { Antal et al. } \\
\text { 2011b }\end{array}$ & $\mathrm{Oz}, 35 \mathrm{~cm}^{2}$ & $\mathrm{Cz}, 35 \mathrm{~cm}^{2}$ & $\begin{array}{l}1.0 \mathrm{~mA} \text { for } 15 \mathrm{~min} \\
(3 \text { session a week, } \\
3 \text { months })\end{array}$ & $\begin{array}{l}\text { Cathodal, } \\
\text { sham }\end{array}$ & Offline & $\begin{array}{l}\text { 26, clinical, } \\
\text { between } \\
\text { participants }\end{array}$ & $\begin{array}{l}\text { Migraine patients tested } \\
\text { for frequency, intensity } \\
\text { and duration of } \\
\text { migraine attacks }\end{array}$ \\
\hline $\begin{array}{l}\text { Bocci et al. } \\
2015\end{array}$ & $\begin{array}{l}\text { *Cerebellum, } \\
\text { Unspecified } \\
\text { size }\end{array}$ & $\begin{array}{l}\text { Unspecified size } \\
\text { and site }\end{array}$ & $2.0 \mathrm{~mA}$ for $20 \mathrm{~min}$ & $\begin{array}{l}\text { Anodal, } \\
\text { cathodal, } \\
\text { sham }\end{array}$ & Offline & $\begin{array}{l}\text { 12, within } \\
\text { participants }\end{array}$ & $\begin{array}{l}\text { Healthy participants } \\
\text { tested with laser } \\
\text { evoked potentials } \\
\text { (right hand stimulation) }\end{array}$ \\
\hline $\begin{array}{l}\text { Boggio et al } \\
2008\end{array}$ & $\begin{array}{l}\mathrm{C} 3, \mathrm{~F} 3, \mathrm{~V} 1 \\
\quad 35 \mathrm{~cm}^{2}\end{array}$ & $\begin{array}{l}\text { Contralateral } \\
\text { supraorbital, } \\
35 \mathrm{~cm}^{2}\end{array}$ & $2.0 \mathrm{~mA}$ for $5 \mathrm{~min}$ & Anodal, sham & Online & $\begin{array}{l}\text { 20, within } \\
\text { participants }\end{array}$ & $\begin{array}{l}\text { Healthy participants } \\
\text { tested for pain } \\
\text { thresholds (peripheral } \\
\text { electrical stimulation) }\end{array}$ \\
\hline $\begin{array}{l}\text { Boggio et al } \\
2009 \mathrm{a}\end{array}$ & $\begin{array}{l}\mathrm{C} 3, \mathrm{~F} 3, \mathrm{~V} 1 \\
35 \mathrm{~cm}^{2}\end{array}$ & $\begin{array}{l}\text { Contralateral } \\
\text { supraorbital, } \\
35 \mathrm{~cm}^{2}\end{array}$ & $2.0 \mathrm{~mA}$ for $5 \mathrm{~min}$ & Anodal, sham & Online & $\begin{array}{l}\text { 23, within } \\
\text { participants }\end{array}$ & $\begin{array}{l}\text { Healthy participants rated } \\
\text { images of painful } \\
\text { situations with respect } \\
\text { the affective valence } \\
\text { and emotional } \\
\text { discomfort it elicited }\end{array}$ \\
\hline $\begin{array}{l}\text { Boggio et al. } \\
2009 \mathrm{~b}\end{array}$ & $\begin{array}{l}\mathrm{C} 3, \mathrm{C} 4, \\
35 \mathrm{~cm}^{2}\end{array}$ & $\begin{array}{l}\text { Contralateral } \\
\text { supraorbital, } \\
35 \mathrm{~cm}^{2}\end{array}$ & $2.0 \mathrm{~mA}$ for $30 \mathrm{~min}$ & Anodal, sham & Offline & $\begin{array}{l}\text { Eight, clinical, } \\
\text { within } \\
\text { participants }\end{array}$ & $\begin{array}{l}\text { Chronic pain patients } \\
\text { tested for subjective } \\
\text { pain rating, cognitive } \\
\text { measures (Stroop test, } \\
\text { etc.), after tDCS alone or } \\
\text { tDCS + transcutaneous } \\
\text { electric nerve } \\
\text { stimulation (TENS) }\end{array}$ \\
\hline $\begin{array}{l}\text { Bolognini } \\
\text { et al. } 2013\end{array}$ & $\begin{array}{l}\mathrm{C} 3 \text { or } \mathrm{C} 4, \\
\mathrm{P} 3 \text { or } \mathrm{P} 4 \\
35 \mathrm{~cm}^{2}\end{array}$ & $\begin{array}{l}\text { Contralateral } \\
\text { supraorbital, } \\
35 \mathrm{~cm}^{2}\end{array}$ & $\begin{array}{l}2.0 \mathrm{~mA} \text { for } 20 \mathrm{~min} \\
\text { (single or three } \\
\text { times/day session) }\end{array}$ & $\begin{array}{l}\text { Anodal, } \\
\text { cathodal, } \\
\text { sham }\end{array}$ & Offline & $\begin{array}{l}\text { Eight, clinical, } \\
\text { within } \\
\text { participants }\end{array}$ & $\begin{array}{l}\text { Phantom limb pain patients } \\
\text { tested for subjective pain } \\
\text { ratings }\end{array}$ \\
\hline $\begin{array}{l}\text { Borckardt } \\
\text { et al. } 2011\end{array}$ & $\mathrm{~T} 4-\mathrm{C} 4,35 \mathrm{~cm}^{2}$ & $\mathrm{~F} 3,35 \mathrm{~cm}^{2}$ & $\begin{array}{l}2.0 \mathrm{~mA} \text { for } 20 \mathrm{~min} \\
\text { (daily sessions for } \\
10 \text { days) }\end{array}$ & Anodal, sham & Offline & $\begin{array}{l}\text { 21, clinical, } \\
\text { between } \\
\text { participants }\end{array}$ & $\begin{array}{l}\text { Endoscopy patients } \\
\text { evaluated for the } \\
\text { amount of analgesics } \\
\text { taken after the } \\
\text { procedure and } \\
\text { subjective pain ratings }\end{array}$ \\
\hline $\begin{array}{l}\text { Borckardt } \\
\quad \text { et al. } 2012\end{array}$ & $\begin{array}{l}\text { *Abductor } \\
\text { brevis } \\
\text { M1 (TMS } \\
\text { confirmed), } \\
\text { HD-tDCS. }\end{array}$ & HD-tDCS & $\begin{array}{l}2.0 \mathrm{~mA} \text { for } 30 \mathrm{~min} \\
(4 \text { sessions in } \\
2 \text { days })\end{array}$ & Anodal, sham & Offline & $\begin{array}{l}\text { 24, between } \\
\text { participants }\end{array}$ & $\begin{array}{l}\text { Healthy volunteers tested } \\
\text { for heat, cold and } \\
\text { mechanical pain } \\
\text { thresholds }\end{array}$ \\
\hline $\begin{array}{l}\text { Borckardt } \\
\text { et al. } 2013\end{array}$ & $\begin{array}{l}\mathrm{C} 1, \mathrm{C} 2 \\
16 \mathrm{~cm}^{2}\end{array}$ & $\mathrm{~F} 3,16 \mathrm{~cm}^{2}$ & $\begin{array}{l}2.0 \mathrm{~mA} \text { for } 20 \mathrm{~min} \\
(4 \text { sessions in } \\
2 \text { days })\end{array}$ & Anodal, sham & Offline & $\begin{array}{l}\text { 40, clinical, } \\
\text { between } \\
\text { participants }\end{array}$ & $\begin{array}{l}\text { Knee arthroplasty patients } \\
\text { evaluated for amount } \\
\text { of analgesics } \\
\text { consumed post-surgery }\end{array}$ \\
\hline $\begin{array}{l}\text { Fregni et al. } \\
2006 \mathrm{~b}\end{array}$ & $\begin{array}{l}\mathrm{C} 3, \mathrm{~F} 3, \\
\quad 35 \mathrm{~cm}^{2}\end{array}$ & $\begin{array}{l}\text { Contralateral } \\
\text { supraorbital, } \\
35 \mathrm{~cm}^{2}\end{array}$ & $\begin{array}{l}2.0 \mathrm{~mA} \text { for } 20 \mathrm{~min} \\
\text { (daily sessions, } \\
5 \text { days) }\end{array}$ & Anodal, sham & Offline & $\begin{array}{l}\text { 32, clinical, } \\
\text { between } \\
\text { participants }\end{array}$ & $\begin{array}{l}\text { Fibromyalgia patients } \\
\text { tested for number of } \\
\text { tender points, subjective } \\
\text { pain scores and other } \\
\text { questionnaires }\end{array}$ \\
\hline $\begin{array}{l}\text { Fregni et al. } \\
\quad 2006 \mathrm{c}\end{array}$ & $\begin{array}{l}\mathrm{C} 3, \mathrm{C} 4 \\
\quad 35 \mathrm{~cm}^{2}\end{array}$ & $\begin{array}{l}\text { Contralateral } \\
\text { supraorbital, } \\
35 \mathrm{~cm}^{2}\end{array}$ & $\begin{array}{l}2.0 \mathrm{~mA} \text { for } 20 \mathrm{~min} \\
\text { (daily sessions, } \\
5 \text { days) }\end{array}$ & Anodal, sham & Offline & $\begin{array}{l}\text { 17, clinical, } \\
\text { between } \\
\text { participants }\end{array}$ & $\begin{array}{l}\text { Spinal chord injured } \\
\text { patients tested for } \\
\text { subjective pain rating, } \\
\text { cognitive measures } \\
\text { (Stroop test, etc.), } \\
\text { anxiety, depression and } \\
\text { other questionnaires }\end{array}$ \\
\hline $\begin{array}{l}\text { Kim et al. } \\
2013\end{array}$ & $\begin{array}{l}\mathrm{C} 3, \mathrm{~F} 3, \\
25 \mathrm{~cm}^{2}\end{array}$ & $\begin{array}{l}\text { Contralateral } \\
\text { supraorbital, } \\
25 \mathrm{~cm}^{2}\end{array}$ & $\begin{array}{l}2.0 \mathrm{~mA} \text { for } 20 \mathrm{~min} \\
\text { (daily sessions, } \\
5 \text { days) }\end{array}$ & Anodal, sham & Offline & $\begin{array}{l}60 \text {, clinical, } \\
\text { between } \\
\text { participants }\end{array}$ & $\begin{array}{l}\text { Patients with painful } \\
\text { diabetic polyneuropathy } \\
\text { tested for pressure pain }\end{array}$ \\
\hline
\end{tabular}


Table 5 (continued)

\begin{tabular}{|c|c|c|c|c|c|c|c|}
\hline Reference & $\begin{array}{l}\text { Location of } \\
\text { target electrode } \\
\text { (international } \\
10-20 \text { system)* }\end{array}$ & $\begin{array}{l}\text { Location of } \\
\text { return electrode }\end{array}$ & Stimulation parameters & $\begin{array}{l}\text { Stimulation } \\
\text { types }\end{array}$ & $\begin{array}{l}\text { tDCS } \\
\text { protocol }\end{array}$ & $\begin{array}{l}\text { Sample size and } \\
\text { design }\end{array}$ & $\begin{array}{l}\text { Outcome measures and } \\
\text { comments }\end{array}$ \\
\hline & & & & & & & $\begin{array}{l}\text { thresholds, subjective } \\
\text { pain, quality of life and } \\
\text { other questionnaires }\end{array}$ \\
\hline $\begin{array}{l}\text { Kumru et al. } \\
2013\end{array}$ & $\begin{array}{r}\mathrm{C} 3 \text { or } \mathrm{C} 4 \\
35 \mathrm{~cm}^{2}\end{array}$ & $\begin{array}{l}\text { Contralateral } \\
\text { supraorbital, } \\
35 \mathrm{~cm}^{2}\end{array}$ & $\begin{array}{l}2.0 \mathrm{~mA} \text { for } 20 \mathrm{~min} \\
\text { (daily sessions } \\
\text { for } 10 \text { days) }\end{array}$ & Anodal, sham & Offline & $\begin{array}{l}\text { 52, clinical, } \\
\text { between } \\
\text { participants }\end{array}$ & $\begin{array}{l}\text { Spinal cord injured } \\
\text { patients tested for } \\
\text { subjective pain ratings } \\
\text { and thermal sensitivity } \\
\text { after a treatment with } \\
\text { tDCS alone or coupled } \\
\text { with a visual illusion } \\
\text { based therapy }\end{array}$ \\
\hline $\begin{array}{l}\text { Mori et al. } \\
2010\end{array}$ & $\begin{array}{l}\mathrm{C} 3, \mathrm{C} 4, \\
\quad 35 \mathrm{~cm}^{2}\end{array}$ & $\begin{array}{l}\text { Contralateral } \\
\text { supraorbital, } \\
35 \mathrm{~cm}^{2}\end{array}$ & $\begin{array}{l}2.0 \mathrm{~mA} \text { for } 20 \mathrm{~min} \\
\text { (daily sessions, } \\
5 \text { days) }\end{array}$ & Anodal, sham & Offline & $\begin{array}{l}\text { 19, clinical, } \\
\text { between } \\
\text { participants }\end{array}$ & $\begin{array}{l}\text { Multiple sclerosis patients } \\
\text { tested for subjective } \\
\text { pain ratings, quality of } \\
\text { life and other } \\
\text { questionnaires }\end{array}$ \\
\hline $\begin{array}{l}\text { Naylor et al. } \\
2013\end{array}$ & $\mathrm{~F} 3,16 \mathrm{~cm}^{2}$ & $\begin{array}{l}\text { Left upper arm, } \\
\qquad 16 \mathrm{~cm}^{2}\end{array}$ & $2.0 \mathrm{~mA}$ for $20 \mathrm{~min}$ & $\begin{array}{l}\text { Anodal, } \\
\text { cathodal, } \\
\text { sham }\end{array}$ & Online & $\begin{array}{l}\text { 41, between } \\
\text { participants }\end{array}$ & $\begin{array}{l}\text { Healthy volunteers tested } \\
\text { in a perceived pain } \\
\text { control task and } \\
\text { subjective pain ratings }\end{array}$ \\
\hline $\begin{array}{l}\text { Plow et al. } \\
\text { 2012c }\end{array}$ & $\mathrm{Oz}, 35 \mathrm{~cm}^{2}$ & $\mathrm{Cz}, 35 \mathrm{~cm}^{2}$ & $\begin{array}{l}1.0 \mathrm{~mA} \text { for } 15 \mathrm{~min} \\
(3 \text { session a week, } \\
3 \text { months })\end{array}$ & $\begin{array}{l}\text { Cathodal, } \\
\text { sham }\end{array}$ & Offline & $\begin{array}{l}\text { 26, clinical, } \\
\text { between } \\
\text { participants }\end{array}$ & $\begin{array}{l}\text { Chronic neuropathic pain } \\
\text { patients }\end{array}$ \\
\hline $\begin{array}{l}\text { Riberto et al. } \\
2011\end{array}$ & $\mathrm{C} 3,35 \mathrm{~cm}^{2}$ & $\begin{array}{l}\text { Contralateral } \\
\text { supraorbital, } \\
35 \mathrm{~cm}^{2}\end{array}$ & $\begin{array}{l}2.0 \mathrm{~mA} \text { for } 20 \mathrm{~min} \\
\text { (weekly sessions } \\
\text { for } 10 \text { weeks) }\end{array}$ & Anodal, sham & Offline & $\begin{array}{l}\text { 23, clinical, } \\
\text { between } \\
\text { participants }\end{array}$ & $\begin{array}{l}\text { Fibromyalgia patients } \\
\text { tested for number } \\
\text { subjective pain scores, } \\
\text { quality of life and other } \\
\text { questionnaires after a } \\
\text { treatment coupling } \\
\text { tDCS and } \\
\text { multidisciplinary } \\
\text { rehabilitation program }\end{array}$ \\
\hline $\begin{array}{l}\text { Schabrun } \\
\quad \text { et al. } 2014\end{array}$ & $\begin{array}{l}* 1 \mathrm{~cm} \text { anterior } \\
\text { and } 4 \mathrm{~cm} \\
\text { lateral to } \\
\text { the vertex, } \\
35 \mathrm{~cm}^{2}\end{array}$ & $\begin{array}{l}\text { Contralateral } \\
\text { supraorbital, } \\
35 \mathrm{~cm}^{2}\end{array}$ & $\begin{array}{l}1.0 \mathrm{~mA} \text { for } 30 \mathrm{~min} \\
\text { (weekly sessions } \\
\text { for } 10 \text { weeks) }\end{array}$ & Anodal, sham & Offline & $\begin{array}{l}\text { 16, clinical, } \\
\text { between } \\
\text { participants }\end{array}$ & $\begin{array}{l}\text { Chronic low back pain } \\
\text { patients pressure pain } \\
\text { threshold, thresholds } \\
\text { for two point } \\
\text { discrimination, } \\
\text { subjective pain ratings } \\
\text { and electromyography } \\
\text { after tDCS and } \\
\text { peripheral electric } \\
\text { stimulation }\end{array}$ \\
\hline $\begin{array}{l}\text { Soler et al. } \\
\quad 2010\end{array}$ & $\begin{array}{l}\mathrm{C} 3 \text { or } \mathrm{C} 4 \\
35 \mathrm{~cm}^{2}\end{array}$ & $\begin{array}{l}\text { Contralateral } \\
\text { supraorbital, } \\
35 \mathrm{~cm}^{2}\end{array}$ & $\begin{array}{l}2.0 \mathrm{~mA} \text { for } 20 \mathrm{~min} \\
\text { (daily sessions for } \\
10 \text { days) }\end{array}$ & Anodal, sham & Offline & $\begin{array}{l}\text { 40, clinical, } \\
\text { between } \\
\text { participants }\end{array}$ & $\begin{array}{l}\text { Spinal cord injured } \\
\text { patients tested for } \\
\text { subjective pain ratings } \\
\text { after a treatment with } \\
\text { tDCS alone or coupled } \\
\text { with a visual illusion } \\
\text { based therapy }\end{array}$ \\
\hline $\begin{array}{l}\text { Valle et al. } \\
2009\end{array}$ & $\begin{array}{l}\mathrm{C} 3, \mathrm{~F} 3, \\
35 \mathrm{~cm}^{2}\end{array}$ & $\begin{array}{l}\text { Contralateral } \\
\text { supraorbital, } \\
35 \mathrm{~cm}^{2}\end{array}$ & $\begin{array}{l}2.0 \mathrm{~mA} \text { for } 20 \mathrm{~min} \\
\text { (daily sessions, } \\
10 \text { days) }\end{array}$ & Anodal, sham & Offline & $\begin{array}{l}\text { 41, clinical, } \\
\text { between } \\
\text { participants }\end{array}$ & $\begin{array}{l}\text { Fibromyalgia patients } \\
\text { tested for number of } \\
\text { tender points, subjective } \\
\text { pain scores and other } \\
\text { questionnaires }\end{array}$ \\
\hline
\end{tabular}

Studies in alphabetical order

*Asterisks mark the studies that do not employ the International 10-20 electrode placement system. Whenever an electrode was placed between two 10-20 coordinates, these coordinates are connected by a "“_“ (e.g., F3-FP1) 
source. In order to investigate the brain areas involved in the production of these illusions, Bolognini et al. (2011) tested occipital, temporal, and posterior parietal cortices tDCS effects over a sound-induced flash illusion task. Temporal and occipital anodal tDCS increased and decreased fission-type responses, respectively. Also, cathodal tDCS over the same areas resulted in the exact opposite effect. Meanwhile the PPC was not detectably involved. Thus, results elucidate the causal association between neural activity in the occipital and temporal areas indicating that an increase or decrease of one modality input affects the integration between two sensory inputs.

A different pattern of results was found in a recent investigation into the role of the PPC and superior temporal sulcus (STS) in the McGurk illusion (Marques et al., 2014). The McGurk illusion consists of the fusion or combination of two competing stimuli: a visual stimulus of a face saying one syllable and the auditory presentation of a different syllable (e.g., MacDonald \& McGurk, 1978). In an investigation of multisensory integration of speech signals, Marques et al. (2014) have modulated the STS and PPC using tDCS. The authors have found the STS cathodal tDCS led to a decrease in illusion response and cathodal PPC led to an increase illusion responses. This study has helped to link both PPC and STS in multisensory speech integration and suggests differential roles for these areas in this process. It is also important to note how the role of the PPC is distinct from what was found for a nonspeech audiovisual illusion in the work of Bolognini et al. (2011) cited above. Taken together, Bolognini et al. (2011) and Marques et al. (2014) illustrate how tDCS can be used to investigate how a multisensory integration area might be differentially engaged in different tasks (even when the same modalities are involved).

However, neuromodulatory effects had also shed light in other associative areas playing a role in visuomotor tasks. Anodal stimulation of both V5 (middle temporal visual area) and M1 induced a significant increase in correct hand movements during the learning phase of a visually guided tracking task (Antal et al., 2004c). Furthermore, temporal tDCS has been demonstrated to be effective in modulating visuomotor speech perception. Using a go-no-go paradigm of congruency judgment between shapes and non-words (elaborated according to the motor-theory of speech perception), Lapenta et al. (2012) found gender- and polarity-specific effects. Specifically, cathodal tDCS decreased the male rate of correct responses during congruent no-go trials while female performance was unaffected. These results suggest a differential cortical organization according to gender during the processing of this type of multimodal integration (Lapenta et al., 2012). Thus, it is tempting to claim that in the multisensory integration field, tDCS is useful to underscore the causal role of brain regions in different sensory integration processes and, further, that it consists of a novel interesting approach to investigate possible gender differences in associative networks. Finally, physiological measures demonstrated that tDCS can modulate the fronto-parietal network involved in movement perception and learning through imitation, a process that integrates visuomotor aspects, as indexed by modulation of the EEG Mu rhythm (Lapenta et al., 2013).

With regard to visuo- and audio-tactile integration, few studies were performed, however, presenting interesting results of effective modulation on different tasks. Avenanti et al. (2012) combined cathodal tDCS over premotor cortex (PMC) or PPC with TMS motor-evoked potentials during presentation of task-irrelevant sounds near and far from the tactile hand stimuli. Usually sensory events occurring near the body prime motor reactions, so that when the peripersonal space network is intact, visual or auditory stimuli near the hand will reduce the corticospinal excitability, while distant stimuli will not. This study revealed that cathodal PMC abolished motor-evoked potential differences between sounds near and far from the hand while PPC stimulation had no effect. These results highlight the critical role of PMC in the motor coding of the peripersonal space.

In addition, when combining visual and tactile experiments, Convento et al. (2013) showed that simultaneous auditory and tactile stimuli can increase phosphene perception. They applied anodal tDCS over occipital, temporal, and parietal cortices while the subject had phosphene induction via single-pulse TMS alone or combined to either tactile or auditory stimuli. When TMS was applied without combined sensory inputs, occipital anodal tDCS increased phosphene perception. Notwithstanding, when combined to sound stimuli, temporal anodal tDCS increased phosphene perception. Also, when combined with tactile stimuli presentation, parietal anodal tDCS increased phosphene detection. These results further demonstrate that combined crossmodal sensory inputs may increase visual cortex excitability (and therefore increase phosphene perception).

The study of multisensory interactions combined with tDCS was also shown to be applicable to clinical purposes. A recent paper based on the knowledge that multisensory interactions can produce analgesic effects (e.g., viewing one's own body reduces pain levels) tested if tDCS would be able to maximize these effects. Anodal, cathodal, and sham stimulation was delivered over left occipital and centro-parietal areas while subjects rated painful intensity sensations elicited by electrical shocks in two visual contexts: while viewing their hand or with an object occluding the vision of their hands. Anodal tDCS over both occipital and centro-parietal areas resulted in decreased pain ratings. While occipital stimulation affected specifically the condition in which participants could see their hands, centro-parietal stimulation decreased pain ratings independently of the visual condition. The authors suggest that visual areas specific for representing the body are likely to mediate the occipital effects, while centro-parietal 
stimulation might influence activity in relevant pain matrix areas (Mancini et al. 2012).

In sum, tDCS has been shown to be an effective tool to investigate several levels of multisensory integration (See Table 6). It is a valuable tool for determining influences of one sensory modality in another as well as for defining the role of several associative areas in multimodal perception. Furthermore, it can bring forth possible gender differences in associative networks. Finally, considering the fact that no single primary nociceptive- or pain-specific cortex has been found so far, it might consist of a valid approach to explore possible areas involved in pain coding.

\section{How can our understanding of tDCS profit from more perception and psychophysics research?}

So far this review has focused on how research into perception may profit from using tDCS. In this brief section we highlight how our understanding of tDCS effects may also profit from research into perception. As mentioned before, there are still some open questions on tDCS specificity and mechanisms of action. It is also possible to argue that there may be a trend in contemporary research when evaluating tDCS outcomes. Since this is a new technique, in many cases the most standard methods and analyses are used to measure its outcomes. Although this might be safe when dealing with a new technique (from the point of view of validating its effects with very well known phenomena and paradigms), it might lead to significant limitations, as we show below.

As can be seen in most studiesreviewed here, most of the current literature uses measures of reaction time, simple accuracy, or thresholds to assess tDCS effects. Although these are certainly valuable and well established, by simply measuring thresholds it is not possible to clearly understand if changes at suprathreshold levels have occurred. As some might argue (e.g., Teghtsoonian \& Teghtsoonian, 1997), understanding the dynamic range of response of one sensory system is of utmost importance in perceptual science. We are not aware of studies that have investigated tDCS effects in terms of changes in the dynamic range of responses, only in terms of changes in accuracy, reaction time, and thresholds. This is relevant information that could help us to better understand and plan tDCS application both in the clinic and in basic research. Also, only very few works have used Signal Detection Theory approaches so far.

A recent study has approached the issue of tDCS effects in threshold and suprathreshold responses with interesting outcomes. Costa et al. (2015a) have evaluated if the threshold and suprathreshold responses to sinusoidal gratings defined by luminance oscillations were similarly affected by tDCS. The authors used visual evoked potentials for this purpose and found a significant tDCS effect only at suprathreshold levels. This supports the notion that in many cases, measuring only threshold level responses might hide many tDCS outcomes.

Another interesting topic is the functional focality of tDCS. It is possible to argue that contemporary neuroscience has a larger amount of information regarding the structure and function of the neurophysiologic substrate of sensory systems than of higher order cognitive functions. We are well aware of the structure and function of different spatial frequency channels and retinotopy in the visual system, different temporal frequency channels in the auditory system, somatosensory homunculus, and so on. In this context, it is possible to measure the effects of tDCS in a group of well defined and functionally different cells within the stimulated area. This can reveal valuable information on tDCS functional focality and mechanisms of action in the living adult brain and only very few studies have used this approach so far.

In fact, a few recent publications support the notion that although tDCS might have a low spatial focality, it might affect different cell groups in the stimulated area in different ways. There is some evidence that the function of different cell groups within the early visual cortex (e.g., different spatial frequency channels, different visual field eccentricities) were distinctively affected by the same tDCS stimulation polarity on a number of occasions (Costa et al., 2012, 2015a, b, c). There is also evidence for some selectivity in the auditory cortex, as supported by specific tDCS effects on one temporal frequency band (Ladeira et al., 2011).

Although the possible differential effects of tDCS on different cell groups within the stimulated area still needs to be further investigated (and to be directly demonstrated with direct electrophysiologic recordings), researchers are advised to be aware of the fact that different cell groups in one area might not be affected in the same way by tDCS. This could happen for a number of reasons, such as effects of cell orientation (where cells in different orientations might be affected in different ways by the same current), changes in resource consumption (where the performance boost in one group of cells might lead to an increase in resource consumption for that cell group only), and differential effects on different neurotransmitter systems (see Costa et al., 2015a for a discussion). More psychophysical research evaluating how tDCS might differentially affect functions that are known to be processed by different cell groups within one specific brain area might help us to understand the extent of these effects and the mechanisms behind it.

We believe that the hypothesis presented here makes a case for how tDCS research may profit from investigations carried out with more sophisticated psychophysical methods and from investigations that employ state of the art knowledge of sensory/perceptual function and linking hypotheses. We have presented a couple of examples on how contemporary research still does not achieve that, but there are certainly many 
Table 6 Summary of parameters and details for each experimental study discussed in the section "Multisensory integration"

\begin{tabular}{|c|c|c|c|c|c|c|c|}
\hline Reference & $\begin{array}{l}\text { Location of } \\
\text { target electrode } \\
\text { (international } \\
10-20 \text { system)* }\end{array}$ & $\begin{array}{l}\text { Location of } \\
\text { return electrode }\end{array}$ & $\begin{array}{l}\text { Stimulation } \\
\text { parameters }\end{array}$ & $\begin{array}{l}\text { Stimulation } \\
\text { types }\end{array}$ & $\begin{array}{l}\text { tDCS } \\
\text { protocol }\end{array}$ & $\begin{array}{l}\text { Sample size and } \\
\text { design }\end{array}$ & $\begin{array}{l}\text { Outcome measures and } \\
\text { comments }\end{array}$ \\
\hline $\begin{array}{l}\text { Antal et al. } \\
2004 \mathrm{c}\end{array}$ & $\begin{array}{l}\text { *V5 (located with } \\
\text { TMS and MRI } \\
\text { model), M1 hand } \\
\text { area (TMS), Oz, } \\
35 \mathrm{~cm}^{2}\end{array}$ & $\begin{array}{l}\mathrm{Cz}, \text { Contralateral } \\
\quad \text { orbit, } 35 \mathrm{~cm}^{2}\end{array}$ & $\begin{array}{l}1.0 \mathrm{~mA} \text { for } \\
10 \mathrm{~min}\end{array}$ & Anodal, sham & $\begin{array}{l}\text { Online and } \\
\text { offline }\end{array}$ & $\begin{array}{l}\text { 12, within } \\
\text { participants }\end{array}$ & $\begin{array}{l}\text { tDCS during learning } \\
\text { phase of a visual-motor } \\
\text { integration task }\end{array}$ \\
\hline $\begin{array}{l}\text { Avenanti et al. } \\
2012\end{array}$ & $\begin{array}{l}\text { *Neuronavigated V1, } \\
\text { PPC and PMC, } \\
35 \mathrm{~cm}^{2}\end{array}$ & $\begin{array}{l}\text { Supraorbital, } \\
35 \mathrm{~cm}^{2}\end{array}$ & $\begin{array}{l}1.0 \mathrm{~mA} \text { for } \\
15 \mathrm{~min}\end{array}$ & $\begin{array}{l}\text { Cathodal, } \\
\text { sham }\end{array}$ & Offline & $\begin{array}{l}\text { 44, within } \\
\text { participants }\end{array}$ & $\begin{array}{l}\text { Motor potentials evoked } \\
\text { by TMS pulses while a } \\
\text { sound was presented } \\
\text { near or distant from the } \\
\text { participant }\end{array}$ \\
\hline $\begin{array}{l}\text { Bolognini et al. } \\
\text { 2010a }\end{array}$ & $\mathrm{P} 4, \mathrm{O} 2,35 \mathrm{~cm}^{2}$ & $\begin{array}{l}\text { Contralateral } \\
\text { deltoid, } \\
35 \mathrm{~cm}^{2}\end{array}$ & $\begin{array}{l}2.0 \mathrm{~mA} \text { for } \\
15 \mathrm{~min}\end{array}$ & Anodal, sham & Offline & $\begin{array}{l}\text { 46, between } \\
\text { participants }\end{array}$ & $\begin{array}{l}\text { Subjects tested in a visual } \\
\text { auditory integration } \\
\text { task }\end{array}$ \\
\hline $\begin{array}{l}\text { Bolognini et al. } \\
\text { 2010b }\end{array}$ & $\mathrm{P} 3, \mathrm{P} 4,35 \mathrm{~cm}^{2}$ & $\begin{array}{l}\text { Contralateral } \\
\text { deltoid, } \\
35 \mathrm{~cm}^{2}\end{array}$ & $\begin{array}{l}2.0 \mathrm{~mA} \text { for } \\
30 \mathrm{~min}\end{array}$ & Anodal, sham & $\begin{array}{l}\text { Online and } \\
\text { offline }\end{array}$ & $\begin{array}{l}\text { 30, between } \\
\text { participants }\end{array}$ & $\begin{array}{l}\text { Visual scanning and } \\
\text { visuo-spatial orientation } \\
\text { performance before and } \\
\text { after an audiovisual } \\
\text { spatial exploration } \\
\text { training }\end{array}$ \\
\hline $\begin{array}{l}\text { Bolognini et al. } \\
2011\end{array}$ & $\begin{array}{l}\mathrm{P} 4, \mathrm{~T} 4, \mathrm{O} 2 \\
\quad 35 \mathrm{~cm}^{2}\end{array}$ & $\begin{array}{l}\text { Contralateral } \\
\text { supraorbital, } \\
35 \mathrm{~cm}^{2}\end{array}$ & $\begin{array}{l}2.0 \mathrm{~mA} \text { for } \\
8 \mathrm{~min}\end{array}$ & Anodal, sham & $\begin{array}{l}\text { Online and } \\
\text { offline }\end{array}$ & $\begin{array}{l}\text { 12, within } \\
\text { participants }\end{array}$ & $\begin{array}{l}\text { Fission and fusion sound- } \\
\text { induced flash illusion }\end{array}$ \\
\hline $\begin{array}{l}\text { Convento et al. } \\
2013\end{array}$ & $\begin{array}{l}\mathrm{T} 4, \mathrm{P} 4, \mathrm{O} 2 \\
\quad 25 \mathrm{~cm}^{2}\end{array}$ & $\begin{array}{l}\text { Contralateral } \\
\text { Supraorbital, } \\
\mathrm{Cz}, 25 \mathrm{~cm}^{2}\end{array}$ & $\begin{array}{l}2.0 \mathrm{~mA} \text { for } \\
10 \mathrm{~min}\end{array}$ & Anodal, sham & Offline & $\begin{array}{l}\text { 40, within and } \\
\text { between } \\
\text { participants }\end{array}$ & $\begin{array}{l}\text { Phosphene thresholds } \\
\text { measured by TMS after } \\
\text { stimulation with auditory } \\
\text { and tactile stimuli }\end{array}$ \\
\hline $\begin{array}{l}\text { Lapenta et al. } \\
2012\end{array}$ & $\begin{array}{l}\text { Simultaneous T3 } \\
\text { and } \mathrm{T} 4,35 \mathrm{~cm}^{2}\end{array}$ & $\begin{array}{l}\text { Right deltoid, } \\
35 \mathrm{~cm}^{2}\end{array}$ & $\begin{array}{l}1.0 \mathrm{~mA} \text { for } \\
14 \mathrm{~min}\end{array}$ & $\begin{array}{l}\text { Anodal, } \\
\text { cathodal, } \\
\text { sham }\end{array}$ & Online & $\begin{array}{l}\text { 28, between } \\
\text { participants }\end{array}$ & $\begin{array}{l}\text { Subject performed a } \\
\text { go-no-go visual/verbal } \\
\text { integration task. This } \\
\text { experiment used } \\
\text { bi-hemispheric tDCS } \\
\text { with the same electrode } \\
\text { polarity in each } \\
\text { hemisphere }\end{array}$ \\
\hline $\begin{array}{l}\text { Lapenta et al. } \\
2013\end{array}$ & $\mathrm{C} 3,35 \mathrm{~cm}^{2}$ & $\begin{array}{l}\text { Supraorbital, } \\
35 \mathrm{~cm}^{2}\end{array}$ & $\begin{array}{l}2.0 \mathrm{~mA} \text { for } \\
20 \mathrm{~min}\end{array}$ & $\begin{array}{l}\text { Anodal, } \\
\text { cathodal, } \\
\text { sham }\end{array}$ & Offline & $\begin{array}{l}\text { 21, within } \\
\text { participants }\end{array}$ & $\begin{array}{l}\text { Electroencephalographic } \\
\text { responses of observation } \\
\text { and imagery of } \\
\text { biological and non- } \\
\text { biological motion }\end{array}$ \\
\hline $\begin{array}{l}\text { Mancini et al. } \\
2012\end{array}$ & $\begin{array}{l}\mathrm{CP} 4-\mathrm{C} 4, \mathrm{O} 2 \\
35 \mathrm{~cm}^{2}\end{array}$ & $\mathrm{FP} 3,35 \mathrm{~cm}^{2}$ & $\begin{array}{l}2.0 \mathrm{~mA} \text { for } \\
10 \mathrm{~min}\end{array}$ & $\begin{array}{l}\text { Anodal, } \\
\text { cathodal, } \\
\text { sham }\end{array}$ & Offline & $\begin{array}{l}\text { 24, within and } \\
\text { between } \\
\text { participants }\end{array}$ & $\begin{array}{l}\text { Subjective pain ratings } \\
\text { after electric painful } \\
\text { stimuli delivered two the } \\
\text { hand in two conditions: } \\
\text { viewing and not } \\
\text { viewing the hand }\end{array}$ \\
\hline $\begin{array}{l}\text { Marques et al. } \\
2014\end{array}$ & $\begin{array}{l}\text { Simultaneous T3 } \\
\text { and T4 or P3 } \\
\text { and } \mathrm{P} 4,35 \mathrm{~cm}^{2}\end{array}$ & $\begin{array}{l}\text { Right deltoid, } \\
35 \mathrm{~cm}^{2}\end{array}$ & $\begin{array}{l}2.0 \mathrm{~mA} \text { for } \\
20 \mathrm{~min}\end{array}$ & $\begin{array}{l}\text { Anodal, } \\
\text { cathodal, } \\
\text { sham }\end{array}$ & Online & $\begin{array}{l}\text { 24, within } \\
\text { participants }\end{array}$ & $\begin{array}{l}\text { Number of McGurk } \\
\text { illusion-type and eye } \\
\text { tracking. This } \\
\text { experiment used } \\
\text { bi-hemispheric tDCS } \\
\text { with the same electrode } \\
\text { polarity in each } \\
\text { hemisphere }\end{array}$ \\
\hline
\end{tabular}

Studies in alphabetical order

*Asterisks mark the studies that do not employ the International 10-20 electrode placement system. Whenever an electrode was placed between two 1020 coordinates, these coordinates are connected by a “_“"(e.g., F3-FP1) 
other relevant questions that will be addressed as this technique becomes more popular.

\section{Summary of some popular approaches in tDCS research}

Here we present some of the general and most popular uses of tDCS in contemporary research. This section shows each of these possible strategies in a general and straightforward style.

(1) Establish causality in brain-behavior relationships: using tDCS to disrupt or boost the activity of one area while measuring how it affects behavior may help to establish stronger causal links between one specific brain area and the task performed. Earlier sections in this review show examples of this approach.

(2) Rehabilitation research: this is one of the most frequent uses of tDCS (in depression or stroke rehabilitation, for instance) and many successful examples of this approach can be found in the second half of each of the sections in this revuew. Two main approaches are used here: stimulating an area where an increase in activity is needed or inhibiting an area that exerts an inhibitory influence over the area for which performance needs to be boosted. Both strategies can also be used simultaneously.

(3) Investigate hemispherical differences : the function of one hemisphere can be boosted while the homologous area of the other hemisphere is inhibited. The outcome of this interhemispheric unbalancing can then be measured. Alternatively, each hemisphere could be stimulated one at a time in a repeated-measures design. One possible example is the study of Bardi et al. (2013) investigating the hemispherical asymmetry for the processing of high- versus low-salience stimuli in the posterior parietal cortex.

(4) Investigate if the same area mediates two processes or functions: to stimulate one area, measuring two or more functions to see if these are affected in the same way can bring valuable insight about cortical organization (e.g., Iuculano \& Kadosh, 2013). Costa et al. (2012) investigated how different color processing pathways are integrated in the early visual cortex. tDCS was shown to affect the function of different pathways in different ways, suggesting some level of functional or structural segregation of these pathways in the stimulated area.

\section{Conclusions}

This review shows that tDCS is able to induce perceptual changes in several sensory modalities, even affecting multimodal integration. It is clear that the potential of technique to help elucidate brain behavior relationships in perception research is far from completely explored. Furthermore, tDCS was shown to be effective in the rehabilitation of a number of clinical conditions. However, before tDCS can be broadly applied in sensory rehabilitation outside the research laboratory, extensive research is still needed. One of the most urgent points is to increase the understanding of tDCS mechanisms of action. For that purpose, more research using invasive methods must be carried out and for that, the development of non-anesthetized animal models is critical. Currently, one group has been collaborating in the development of such a model for visual system investigations (Costa et al., 2013).

Human research using larger samples and investigating combined tDCS/pharmacologic interventions are advised. Also, since different parameters may lead to different effects, more parametric studies are necessary to optimize tDCS delivery. tDCS effects on different pathways or cell groups within the stimulated area need to be further investigated and the tests employed to evaluate tDCS outcomes must be sensitive enough to detect pathway-specific effects. Also, recently introduced HD-tDCS devices might be useful in this line of research since they deliver a more focal stimulation.

Although it is suggested that tDCS may have a low focality on the spatial domain, its effects can be very focal in the functional domain, differentially affecting different cell groups within the stimulated area (i.e., Borckardt et al. 2013; Costa et al., 2012; Costa et al., 2015a; Ladeira et al., 2011). Since there is some evidence that tDCS might be effective in unveiling gender differences in cortical organization (Lapenta et al., 2012), we must reinforce the need for more research in order for us to better understand the potential of tDCS as a tool to study these gender differences. Nonetheless, its potential to test unresolved controversies in theories and models in perception research (by offering stronger causal evidence on the role of different brain areas) must be highlighted. Compelling illustrations of this were presented in the studies by Cecere et al. (2013), Yau et al. (2014), Heimrath et al. (2014), Costa et al. (2015c), and others.

Altogether, the studies presented here represent a robust illustration of how tDCS may be used for basic research and clinical purposes in perception rehabilitation. In conclusion, tDCS has proven to be a valuable tool in contemporary neuroscience research. Although its use in research on perceptual processes is still less encompassing than in other areas, the studies presented here confirm the applicability of tDCS and its potential to modulate sensory and perceptual phenomena.

Acknowledgments We would like to thank Dr. Simon Grondin, Dr. Lawrence Ward, Dr. Andrea Cancelli, and one anonymous reviewer for their thoughtful suggestions in improving this manuscript. We are extremely grateful to Filipe Costa for providing quality color figures. This work was supported by funding from FAPESP, CAPES, and CNPq. TLC and OML had FAPESP doctoral grants (2011/10794-9 and 2012/246961 , respectively). DFV and PSB are CNPq research fellows. 


\section{References}

Andrade, C. (2013). Once-to twice-daily, 3-year domiciliary maintenance transcranial direct current stimulation for severe, disabling, clozapine-refractory continuous auditory hallucinations in schizophrenia. Journal of ECT, 29(3), 239-242.

Antal, A., \& Paulus, W. (2008). Transcranial direct current stimulation and visual perception. Perception, 37, 367-374.

Antal, A., Kincses, T. Z., Nitsche, M. A., \& Paulus, W. (2003a). Modulation of moving phosphene thresholds by transcranial direct current stimulation of V1 in human. Neuropsychologia, 41, 18021807.

Antal, A., Kincses, T. Z., Nitsche, M. A., \& Paulus, W. (2003b). Manipulation of phosphene thresholds by transcranial direct current stimulation in man. Experimental Brain Research, 150, 375-378.

Antal, A., Kincses, T. Z., Nitsche, M. A., Bartfai, O., \& Paulus, W. (2004a). Excitability changes induced in the human primary visual cortex by transcranial direct current stimulation: Direct electrophysiological evidence. Investigative Ophthalmology \& Visual Science, $45,702-707$.

Antal, A., Kriener, N., Lang, N., Boros, K., \& Paulus, W. (2011a). Cathodal transcranial direct current stimulation of the visual cortex in the prophylactic treatment of migraine. Cephalalgia, 31(7), $820-828$.

Antal, A., Nitsche, M. A., Kincses, T. Z., Kruse, W., Hoffmann, K. P., \& Paulus, W. (2004b). Facilitation of visuo-motor learning by transcranial direct current stimulation of the motor and extrastriate visual areas in humans. European Journal of Neuroscience, 19(10), 28882892.

Antal, A., Nitsche, M., \& Paulus, W. (2011b). Electrical stimulation and visual network plasticity. Restorative Neurology and Neuroscience, $29,365-374$.

Antal, A., Nitsche, M. A., \& Paulus, W. (2001). External modulation of visual perception in humans. NeuroReport, 12, 3553-3555.

Antal, A., Varga, E. T., Nitsche, M. A., Chadaide, Z., Paulus, W., Kovacs, G., \& Vidnyanszky, Z. (2004c). Direct current stimulation over MT+/V5 modulates motion aftereffect in humans. NeuroReport, $15,2491-2494$

Avenanti, A., Annela, L., \& Serino, A. (2012). Suppression of premotor cortex disrupts motor coding of peripersonal space. Neuroimage, 63(1), 281-288.

Bachmann, C. G., Muschinsky, S., Nitsche, M. A., Rolke, R., Magerl, W., Treede, R. D., ... \& Happe, S. (2010). Transcranial direct current stimulation of the motor cortex induces distinct changes in thermal and mechanical sensory percepts. Clinical Neurophysiology, 121(12), 2083-2089.

Bardi, L., Kanai, R., Mapelli, D., \& Walsh, V. (2013). Direct current stimulation (tDCS) reveals parietal asymmetry in local/global and salience-based selection. Cortex, 49(3), $850-860$.

Bikson, M., Rahman, A., \& Datta, A. (2012). Computational models of transcranial direct current stimulation. Clinical EEG and Neuroscience, 43(3), 176-183.

Bindman, L. J., Lippold, O. C., \& Redfearn, J. W. T. (1964). The action of brief polarizing currents on the cerebral cortex of the rat during current flow and in the production of long-lasting after-effects. Journal of Physiology, 172, 369-382.

Bocci, T., Santarcangelo, E., Vannini, B., Torzini, A., Carli, G., Ferrucci, R., ... \& Sartucci, F. (2015). Cerebellar direct current stimulation modulates pain perception in humans. Restorative Neurology and Neuroscience. In press.

Boggio, P. S., Amancio, E. J., Correa, C. F., Cecilio, S., Valasek, C., Bajwa, Z., ... \& Fregni, F. (2009). Transcranial DC stimulation coupled with TENS for the treatment of chronic pain: a preliminary study. Clinical Journal of Pain, 25(8), 691-695.

Boggio, P. S., Zaghi, S., \& Fregni, F. (2009b). Modulation of emotions associated with images of human pain using anodal transcranial direct current stimulation (tDCS). Neuropsychologia, 47(1), 212-217.

Boggio, P. S., Zaghi, S., Lopes, M., \& Fregni, F. (2008). Modulatory effects of anodal transcranial direct current stimulation on perception and pain thresholds in healthy volunteers. European Journal of Neurology, 15(10), 1124-1130.

Boldt, I., Eriks-Hoogland, I., Brinkhof, M. W., de Bie, R., Joggi, D., \& von Elm, E. (2011). Non-pharmacological interventions for chronic pain in people with spinal cord injury. The Cochrane Library.

Bolognini, N., Fregni, F., Casati, C., Olgiati, E., \& Vallar, G. (2010a). Brain polarization of parietal cortex augments training-induced improvement of visual exploratory and attentional skills. Brain Research, 1349, 76-89.

Bolognini, N., Olgiati, E., Maravita, A., Ferraro, F., \& Fregni, F. (2013). Motor and parietal cortex stimulation for phantom limb pain and sensations. Pain, 154(8), 1274-1280.

Bolognini, N., Olgiati, E., Rossetti, A., \& Maravita, A. (2010b). Enhancing multisensory spatial orienting by brain polarization of the parietal cortex. European Journal of Neuroscience, 31(10), $1800-1806$.

Bolognini, N., Rossetti, A., Casati, C., Mancini, F., \& Vallar, G. (2011). Neuromodulation of multisensory perception: a tDCS study of the sound-induced flash illusion. Neuropsychologia, 49, 231-237.

Borckardt, J. J., Bikson, M., Frohman, H., Reeves, S. T., Datta, A., Bansal, V., ... \& George, M. S. (2012). A pilot study of the tolerability and effects of high-definition transcranial direct current stimulation (HD-tDCS) on pain perception. Journal of Pain, 13(2), 112-120.

Borckardt, J. J., Reeves, S. T., Robinson, S. M., May, J. T., Epperson, T. I., Gunselman, R. J., .. \& \& George, M. S. (2013). Transcranial direct current stimulation (tDCS) reduces postsurgical opioid consumption in total knee arthroplasty (TKA). Clinical Journal of Pain, 29(11), 925-928.

Brunelin, J., Mondino, M., Gassab, L., Haesebaert, F., Gaha, L., Suaud-Chagny, M.F., ..., Poulet, E. (2012). Examining transcranial direct-current stimulation (tDCS) as a treatment for hallucinations in schizophrenia. American Journal of Psychiatry 169, 719-724

Brunoni, A. R., Amadera, J., Berbel, B., Volz, M. S., Rizzerio, B. G., \& Fregni, F. (2012). A systematic review on reporting and assessment of adverse effects associated with transcranial direct current stimulation. International Journal of Neuropsychopharmachology, 14, $1133-1145$.

Cecere, R., Bertini, C., \& Làdavas, E. (2013). Differential Contribution of Cortical and Subcortical Visual Pathways to the Implicit Processing of Emotional Faces: A tDCS Study. The Journal of Neuroscience, 33(15), 6469-6475.

Charvet, L., Kasschau, M., Datta, A., Knotkova, H., Stevens, M. C., Alonzo, A., ... \& Bikson, M. (2015). Remotely-Supervised Transcranial Direct Current Stimulation (tDCS) for Clinical Trials: Guidelines for Technology and Protocols. Frontiers in Systems Neuroscience, 9, 26.

Chen, J. C., Hämmerer, D., D'Ostilio, K., Casula, E. P., Marshall, L., Tsai, C. H., Rothwel, J. C., Edwards, M. J. (2014a). Bi-directional modulation of somatosensory mismatch negativity with transcranial direct current stimulation: an event related potential study. Journal of Physiology, 592(4), 745-757.

Chen, J. C., Hämmerer, D., Strigaro, G., Liou, L. M., Tsai, C. H., Rothwell, J. C., \& Edwards, M. J. (2014b). Domain-specific 
suppression of auditory mismatch negativity with transcranial direct current stimulation. Clinical Neurophysiology, 125(3), 585-592.

Convento, S., Vallar, G., Galantini, C., \& Bolognini, N. (2013). Neuromodulation of early multisensory interactions in the visual cortex. Journal of Cognitive Neuroscience, 25(5), 685-696.

Costa, T. L., Costa, M. F., Magalhães, A., Rêgo, G. G., Nagy, B. V., Boggio, P. S., \& Ventura, D. F. (2015a). The role of early stages of cortical visual processing in size and distance judgment: A transcranial direct current stimulation study. Neuroscience Letters, 588, 78-82.

Costa, T. L., Gualtieri, M., Barboni, M. T., Katayama, R. K., Boggio, P. S., \& Ventura, D. F. (2015). Contrasting effects of transcranial direct current stimulation on central and peripheral visual fields. Experimental Brain Research, 1-7.

Costa, T. L., Hamer, R. D., Nagy, B. V., Barboni, M. T., Gualtieri, M., Boggio, P. S., \& Ventura, D. F. (2015). Transcranial direct current stimulation can selectively affect different processing channels in human visual cortex. Experimental Brain Research, 1-11.

Costa, T. L., Nagy, B. V., Barboni, M. T., Boggio, P. S., \& Ventura, D. F. (2012). Transcranial direct current stimulation modulates human color discrimination in a pathway-specific manner. Frontiers in Psychiatry, 3, 1-9.

Costa, T.L., Amman, C., Ioshimoto, G.L., Gruart, A., Delgado-Garcia, J.M., Ventura, D.F., Marquez-Ruiz, J.M. (2013). The Awake Rabbit as a Model For Studies of Transcranial Direct Current Stimulation of The Visual Cortex. IOVS, 54: E-Abstract 3410.

Creutzfeldt, O. D., Fromm, G. H., \& Kapp, H. (1962). Influence of transcortical de-currents on cortical neuronal activity. Experimental Neurology, 5, 436-452.

Datta, A., Bansal, V., Diaz, J., Patel, J., Reato, D., \& Bikson, M. (2009). Gyri-precise head model of transcranial direct current stimulation: improved spatial focality using a ring electrode versus conventional rectangular pad. Brain Stimulation, 2(4), 201-207.

Dieckhöfer, A., Waberski, T. D., Nitsche, M., Paulus, W., Buchner, H., \& Gobbelé, R. (2006). Transcranial direct current stimulation applied over the somatosensory cortex-differential effect on low and high frequency SEPs. Clinical Neurophysiology, 117(10), 2221-2227.

Edwards, D., Cortes, M., Datta, A., Minhas, P., Wassermann, E. M., \& Bikson, M. (2013). Physiological and modeling evidence for focal transcranial electrical brain stimulation in humans: a basis for highdefinition tDCS. Neuroimage, 74, 266-275.

Faber, M., Vanneste, S., Fregni, F., \& De Ridder, D. (2012). Top down prefrontal affective modulation of tinnitus with multiple sessions of tDCS of dorsolateral prefrontal cortex. Brain Stimulation, 5(4), 492-498.

Falcone, B., Coffman, B. A., Clark, V. P., \& Parasuraman, R. (2012). Transcranial direct current stimulation augments perceptual sensitivity and 24-hour retention in a complex threat detection task. PloS one, 7(4), e34993.

Ferrucci, R., Marceglia, S., Vergari, M., Cogiamanian, F., Mrakic-Sposta, S., Mameli, F., ... \& Priori, A. (2008). Cerebellar transcranial direct current stimulation impairs the practice-dependent proficiency increase in working memory. Journal of Cognitive Neuroscience, 20(9), 1687-1697.

Filmer, H. L., Dux, P. E., \& Mattingley, J. B. (2014). Applications of transcranial direct current stimulation for understanding brain function. Trends in Neurosciences, 37(12), 742-753.

Fitzgerald, P. B., McQueen, S., Daskalakis, Z. J., \& Hoy, K. E. (2014). A Negative Pilot Study of Daily Bimodal Transcranial Direct Current Stimulation in Schizophrenia. Brain Stimulation, 7(6), 813-816.

Fregni, F., Boggio, P. S., Lima, M. C., Ferreira, M. J., Wagner, T., Rigonatti, S. P., ... \& Pascual-Leone, A. (2006). A sham-controlled, phase II trial of transcranial direct current stimulation for the treatment of central pain in traumatic spinal cord injury. Pain, 122(1), 197-209.
Fregni, F., Gimenes, R., Valle, A. C., Ferreira, M. J., Rocha, R. R., Natalle, L., ... \& Boggio, P. S. (2006). A randomized, sham-controlled, proof of principle study of transcranial direct current stimulation for the treatment of pain in fibromyalgia. Arthritis \& Rheumatism, 54(12), 3988-3998.

Fregni, F., Liguori, P., Fecteau, S., Nitsche, M. A., Pascual-Leone, A., \& Boggio, P. S. (2008). Cortical stimulation of the prefrontal cortex with transcranial direct current stimulation reduces cue-provoked smoking craving: A randomized, sham-controlled study. Journal of Clinical Psychiatry, 69(1), 32-40.

Fregni, F., Marcondes, R., Boggio, P. S., Marcolin, M. A., Rigonatti, S. P., Sanchez, T. G., Nitsche, M. A., \& Pascual-Leone, A. (2006c). Transient tinnitus suppression induced by repetitive transcranial magnetic stimulation and transcranial direct current stimulation. European Journal of Neurology, 13(9), 996-1001.

Fujimoto, S., Yamaguchi, T., Otaka, Y., Kondo, K., \& Tanaka, S. (2013). Dual-hemisphere transcranial direct current stimulation improves performance in a tactile spatial discrimination task. Clinical Neurophysiology., 125(8), 1669-1674.

Gandiga, P. C., Hummel, F. C., \& Cohen, L. G. (2006). Transcranial DC stimulation (tDCS): A tool for double-blind sham-controlled clinical studies in brain stimulation. Clinical Neurophysiology, 117(4), 845-850.

Garin, P., Gilain, C., Van Damme, J. P., de Fays, K., Jamart, J., Ossemann, M., \& Vandermeeren, Y. (2011). Short-and long-lasting tinnitus relief induced by transcranial direct current stimulation. Journal of Neurology, 258(11), 1940-1948.

Ghazanfar, A. A., \& Schroeder, C. E. (2006). Is neocortex essentially multisensory? Trends in Cognitive Sciences, 10(6), 278-285.

Grundmann, L., Rolke, R., Nitsche, M. A., Pavlakovic, G., Happe, S., Treede, R. D., ... \& Bachmann, C. G. (2011). Effects of transcranial direct current stimulation of the primary sensory cortex on somatosensory perception. Brain Stimulation, 4(4), 253-260.

Guarienti, F., Caumo, W., Shiozawa, P., Cordeiro, Q., Boggio, P. S., Benseñor, I. M., \& Brunoni, A. R. (2014). Reducing Transcranial Direct Current Stimulation-Induced Erythema With Skin Pretreatment: Considerations for Sham-Controlled Clinical Trials. Neuromodulation: Technology at the Neural Interface, In Press.

Halko, M., Datta, A., Plow, E., Scaturro, J., Bikson, M., \& Merabet, L. B. (2011). Neuroplastic changes following rehabilitative training correlate with regional electrical field induced with tDCS. Neuroimage, $57,885-891$

Heimrath, K., Kuehne, M., Heinze, H. J., \& Zaehle, T. (2014). Transcranial direct current stimulation (tDCS) traces the predominance of the left auditory cortex for processing of rapidly changing acoustic information. Neuroscience, 261, 68-73.

Heth, I., \& Lavidor, M. (2015). Improved reading measures in adults with dyslexia following transcranial direct current stimulation treatment. Neuropsychologia, In press.

Impey, D., \& Knott, V. (2015). Effect of transcranial direct current stimulation (tDCS) on MMN-indexed auditory discrimination: a pilot study. Journal of Neural Transmission, 1-11.

Iuculano, T., \& Kadosh, R. C. (2013). The mental cost of cognitive enhancement. Journal of Neuroscience, 33(10), 4482-4486.

Iyer, M. B., Mattu, U., Grafman, J., Lomarev, M., Sato, S., \& Wassermann, E. M. (2005). Safety and cognitive effect of frontal DC brain polarization in healthy individuals. Neurology, 64(5), 872-875.

Kaelin-Lang, A., Luft, A. R., Sawaki, L., Burstein, A. H., Sohn, Y. H., \& Cohen, L. G. (2002). Modulation of human corticomotor excitability by somatosensory input. Journal of Physiology, 540(2), 623-633.

Kim, Y. J., Ku, J., Kim, H. J., Im, D. J., Lee, H. S., Han, K. A., \& Kang, Y. J. (2013). Randomized, sham controlled trial of transcranial direct current stimulation for painful diabetic polyneuropathy. Annals of Rehabilitation Medicine, 37(6), 766-776. 
Kraft, A., Roehmel, J., Olma, M., Schmidt, S., Irlbacher, K., \& Brandt, S. (2010). Transcranial direct current stimulation affects visual perception measured by threshold perimetry. Experimental Brain Research, 207, 283-290.

Kumru, H., Soler, D., Vidal, J., Navarro, X., Tormos, J. M., PascualLeone, A., \& Valls-Sole, J. (2013). The effects of transcranial direct current stimulation with visual illusion in neuropathic pain due to spinal cord injury: An evoked potentials and quantitative thermal testing study. European Journal of Pain, 17(1), 55-66.

Ladeira, A., Fregni, F., Campanhã, C., Valasek, C. A., De Ridder, D., Brunoni, A. R., \& Boggio, P. S. (2011). Polarity-dependent transcranial direct current stimulation effects on central auditory processing. PloS One, 6(9), 1-9. e25399.

Landau, W. M., Bishop, G. H., \& Clare, M. H. (1964). Analysis of the form and distribution of evoked cortical potentials under the influence of polarizing currents. Journal of Neurophysiology, 27, 788-813.

Langguth, B., De Ridder, D., Dornhoffer, J. L., Eichhammer, P., Folmer, R. L., Frank, E., ... \& Hajak, G. (2008). Controversy: Does repetitive transcranial magnetic stimulation/transcranial direct current stimulation show efficacy in treating tinnitus patients? Brain Stimulation, 1(3), 192-205.

Lapenta, O. M., Fregni, F., Oberman, L. M., \& Boggio, P. S. (2012). Bilateral temporal cortex transcranial direct current stimulation worsens male performance in a multisensory integration task. Neuroscience Letters, 527(2), 105-109.

Lapenta, O. M., Minati, L., Fregni, F., \& Boggio, P. S. (2013). Je pense donc je fais: Transcranial direct current stimulation modulates brain oscillations associated with motor imagery and movement observation. Frontiers in Human Neuroscience, 7, 1-9.

Lindenberg, R., Nachtigall, L., Meinzer, M., Sieg, M. M., \& Flöel, A. (2013). Differential effects of dual and unihemispheric motor cortex stimulation in older adults. Journal of Neuroscience, 33(21), 9176-9183.

Loui, P., Hohmann, A., \& Schlaug, G. (2012). Inducing disorders in pitch perception and production: a reverse-engineering approach. In Proceedings of Meetings on Acoustics (Vol. 9, No. 1, p. 050002). Acoustical Society of America.

Macaluso, E., \& Driver, J. (2005). Multisensory spatial interactions: A window onto functional integration in the human brain. Trends in Neurosciences, 28(5), 264-271.

MacDonald, J., \& McGurk, H. (1978). Visual influences on speech perception processes. Perception \& Psychophysics, 24(3), 253-257.

Mancini, F., Bolognini, N., Haggard, P., \& Vallar, G. (2012). Tdcs modulation of visually induced analgesia. Journal of Cognitive Neuroscience, 24(12), 2419-2427.

Marques, L. M., Lapenta, O. M., Merabet, L. B., Bolognini, N., \& Boggio, P. S. (2014). Tuning and disrupting the brain — modulating the McGurk illusion with electrical stimulation. Frontiers in Human Neuroscience, 8 .

Matsunaga, K., Nitsche, M. A., Tsuji, S., \& Rothwell, J. C. (2004). Effect of transcranial DC sensorimotor cortex stimulation on somatosensory evoked potentials in humans. Clinical Neurophysiology, 115(2), 456-460.

McCreery, D. B., Agnew, W. F., Yuen, T. G., \& Bullara, L. (1990). Charge density and charge per phase as cofactors in neural injury induced by electrical stimulation. Biomedical Engineering, IEEE Transactions on, 37(10), 996-1001

McKinley, R. A., McIntire, L., Bridges, N., Goodyear, C., \& Weisend, M. P. (2013). Acceleration of image analyst training with transcranial direct current stimulation. Behavioral Neuroscience, 127(6), 936.

Medeiros, L. F., de Souza, I. C. C., Vidor, L. P., de Souza, A., Deitos, A., Volz, M. S., Fregni, F. Caumo, W. \& Torres, I. L. (2012).
Neurobiological effects of transcranial direct current stimulation: a review. Frontiers in Psychiatry, 3.

Miranda, P. C., Lomarev, M., \& Hallett, M. (2006). Modeling the current distribution during transcranial direct current stimulation. Clinical Neurophysiology, 117(7), 1623-1629.

Monzée, J., Lamarre, Y., \& Smith, A. M. (2003). The effects of digital anesthesia on force control using a precision grip. Journal of Neurophysiology, 89(2), 672-683.

Mori, F., Codecà, C., Kusayanagi, H., Monteleone, F., Buttari, F., Fiore, S., ... \& Centonze, D. (2010). Effects of anodal transcranial direct current stimulation on chronic neuropathic pain in patients with multiple sclerosis. Journal of Pain, 11(5), 436-442.

Mori, F., Nicoletti, C. G., Kusayanagi, H., Foti, C., Restivo, D. A., Marciani, M. G., \& Centonze, D. (2013). Transcranial direct current stimulation ameliorates tactile sensory deficit in multiple sclerosis. Brain Stimulation, 6(4), 654-659.

Moseley, G. L. (2007). Using visual illusion to reduce at-level neuropathic pain in paraplegia. Pain, 130(3), 294-298.

Mylius, V., Borckardt, J. J., \& Lefaucheur, J. P. (2012). Noninvasive cortical modulation of experimental pain. Pain, 153(7), 1350-1363.

Nawani, H., Kalmady, S. V., Bose, A., Shivakumar, V., Rakesh, G., Subramaniam, A., Narayanaswamy, J. C., \& Venkatasubramanian, G. (2014). Neural basis of tDCS effects on auditory verbal hallucinations in schizophrenia: A case report evidence for cortical neuroplasticity modulation. Journal of ECT, 30(1), e2-e4.

Naylor, J. C., Borckardt, J. J., Marx, C. E., Hamer, R. M., Fredrich, S., Reeves, S. T., \& George, M. S. (2013). Cathodal and Anodal Left Prefrontal tDCS and the Perception of Control Over Pain. Clinical Journal of Pain, 30(8), 693-700.

Nitsche, M. A., \& Paulus, W. (2000). Excitability changes induced in the human motor cortex by weak transcranial direct current stimulation. Journal of Physiology, 527(3), 633-639.

Nitsche, M. A., Cohen, L. G., Wassermann, E. M., Priori, A., Lang, N., Antal, A., Paulus, W., Hummel, F., Boggio, P., Fregni, F., \& PascualLeone, A. (2008). Transcranial direct current stimulation: state of the art 2008. Brain Stimulation, 1(3), 206-223.

Nitsche, M. A., Fricke, K., Henschke, U., Schlitterlau, A., Liebetanz, D., Lang, N., Henning, S., Tergau, F., \& Paulus, W. (2003a). Pharmacological modulation of cortical excitability shifts induced by transcranial direct current stimulation in humans. Journal of Physiology, 553(1), 293-301.

Nitsche, M. A., Liebetanz, D., Antal, A., Lang, N., Tergau, F., \& Paulus, W. (2003b). Modulation of cortical excitability by weak direct current stimulation-technical, safety and functional aspects. Supplements to Clinical Neurophysiology, 56, 255.

Nitsche, M. A., Liebetanz, D., Schlitterlau, A., Henschke, U., Fricke, K., Frommann, K., ... \& Tergau, F. (2004). GABAergic modulation of DC stimulation-induced motor cortex excitability shifts in humans. European Journal of Neuroscience, 19(10), 2720-2726.

Nitsche, M. A., Niehaus, L., Hoffmann, K. T., Hengst, S., Liebetanz, D., Paulus, W., \& Meyer, B. U. (2004b). MRI study of human brain exposed to weak direct current stimulation of the frontal cortex. Clinical Neurophysiology, 115(10), 2419-2423.

Olma, M. C., Kraft, A., Roehmel, J., Irlbacher, K., \& Brandt, S. A. (2011). Excitability changes in the visual cortex quantified with signal detection analysis. Restorative Neurology and Neuroscience, 29(6), 453-461.

Olma, M. C., Dargie, R. A., Behrens, J. R., Kraft, A., Irlbacher, K., Fahle, M., \& Brandt, S. A. (2013). Long-term effects of serial anodal tDCS on motion perception in subjects with occipital stroke measured in the unaffected visual hemifield. Frontiers in Human Neuroscience, 7.

Pascual-Leone, A., Walsh, V., \& Rothwell, J. (2000). Transcranial magnetic stimulation in cognitive neuroscience-virtual lesion, 
chronometry, and functional connectivity. Current Opinion in Neurobiology, 10(2), 232-237.

Peters, M. A., Thompson, B., Merabet, L. B., Wu, A. D., \& Shams, L. (2013). Anodal tDCS to V1 blocks visual perceptual learning consolidation. Neuropsychologia, 51(7), 1234-1239.

Plow, E. B., Obretenova, S. N., Fregni, F., Pascual-Leone, A., \& Merabet, L. B. (2012a). Comparison of visual field training for hemianopia with active versus sham transcranial direct cortical stimulation. Neurorehabilitation and Neural Repair, 26(6), 616-626.

Plow, E. B., Obretenova, S. N., Halko, M. A., Kenkel, S., Jackson, M. L., Pascual-Leone, A., \& Merabet, L. B. (2011). Combining visual rehabilitative training and noninvasive brain stimulation to enhance visual function in patients with hemianopia: A comparative case study. $P M \& R, 3(9), 825-835$.

Plow, E. B., Obretenova, S. N., Jackson, M. L., \& Merabet, L. B. (2012b). Temporal profile of functional visual rehabilitative outcomes modulated by transcranial direct current stimulation. Neuromodulation: Technology at the Neural Interface, 15(4), 367-373.

Plow, E. B., Pascual-Leone, A., \& Machado, A. (2012c). Brain Stimulation in the Treatment of Chronic Neuropathic and NonCancerous Pain. Journal of Pain, 13, 411-424.

Priori, A. (2003). Brain polarization in humans: A reappraisal of an old tool for prolonged non-invasive modulation of brain excitability. Clinical Neurophysiology, 114(4), 589-595.

Ragert, P., Vandermeeren, Y., Camus, M., \& Cohen, L. G. (2008). Improvement of spatial tactile acuity by transcranial direct current stimulation. Clinical Neurophysiology, 119(4), 805-811.

Riberto, M., Alfieri, F. M., de Benedetto Pacheco, K. M., Leite, V. D., Kaihami, H. N., Fregni, F., \& Battistella, L. R. (2011). Efficacy of transcranial direct current stimulation coupled with a multidisciplinary rehabilitation program for the treatment of fibromyalgia. Open Rheumatology Journal, 5, 45.

Rogalewski, A., Breitenstein, C., Nitsche, M. A., Paulus, W., \& Knecht, S. (2004). Transcranial direct current stimulation disrupts tactile perception. European Journal of Neuroscience, 20(1), 313-316.

Rossi, S., Hallett, M., Rossini, P. M., Pascual-Leone, A., \& Safety of TMS Consensus Group. (2009). Safety, ethical considerations, and application guidelines for the use of transcranial magnetic stimulation in clinical practice and research. Clinical Neurophysiology, 120(12), 2008-2039.

Schabrun, S. M., Jones, E., Elgueta Cancino, E. L., \& Hodges, P. W. (2014). Targeting Chronic Recurrent Low Back Pain From the Top-down and the Bottom-up: A Combined Transcranial Direct Current Stimulation and Peripheral Electrical Stimulation Intervention. Brain Stimulation, 7(3), 451-459.

Scott, S. K., \& McGettigan, C. (2013). Do temporal processes underlie left hemisphere dominance in speech perception? Brain and Language, 127(1), 36-45.

Shams, L., Kamitani, Y., \& Shimojo, S. (2000). What you see is what you hear. Nature, 408(6814), 988-1007.

Shekhawat, G. S., Stinear, C. M., \& Searchfield, G. D. (2013). Transcranial direct current stimulation intensity and duration effects on tinnitus suppression. Neurorehabilitation and Neural Repair, 27(2), 164-172.

Shenoy, S., Bose, A., Chhabra, H., Dinakaran, D., Agarwal, S. M., Shivakumar, V., ... \& Venkatasubramanian, G. (2015). Transcranial Direct Current Stimulation (tDCS) for Auditory Verbal Hallucinations in Schizophrenia During Pregnancy: A Case Report. Brain Stimulation, 8, 369-370.

Soler, M. D., Kumru, H., Pelayo, R., Vidal, J., Tormos, J. M., Fregni, F., ... \& Pascual-Leone, A. (2010). Effectiveness of transcranial direct current stimulation and visual illusion on neuropathic pain in spinal cord injury. Brain, awq184.
Spiegel, D. P., Li, J., Hess, R. F., Byblow, W. D., Deng, D., Yu, M., \& Thompson, B. (2013). Transcranial direct current stimulation enhances recovery of stereopsis in adults with amblyopia. Neurotherapeutics, 10(4), 831-839.

Stagg, C. J., \& Nitsche, M. A. (2011). Physiological basis of transcranial direct current stimulation. Neuroscientist, 17(1), 37-53.

Stagg, C. J., Best, J. G., Stephenson, M. C., O'Shea, J., Wylezinska, M., Kincses, Z. T., ... \& Johansen-Berg, H. (2009). Polarity-sensitive modulation of cortical neurotransmitters by transcranial stimulation. Journal of Neuroscience, 29(16), 5202-5206.

Sunwoo, H., Kim, Y. H., Chang, W. H., Noh, S., Kim, E. J., \& Ko, M. H. (2013). Effects of dual transcranial direct current stimulation on post-stroke unilateral visuospatial neglect. Neuroscience Letters, 554, 94-98.

Tecchio, F., Cancelli, A., Cottone, C., Zito, G., Pasqualetti, P., Ghazaryan, A., ... \& Filippi, M. M. (2014). Multiple sclerosis fatigue relief by bilateral somatosensory cortex neuromodulation. Journal of Neurology, 261(8), 1552-1558.

Teghtsoonian, R., \& Teghtsoonian, M. (1997). Range of acceptable stimulus intensities: An estimator of dynamic range for intensive perceptual continua. Perception \& Psychophysics, 59(5), 721-728.

Teismann, H., Wollbrink, A., Okamoto, H., Schlaug, G., Rudack, C., \& Pantev, C. (2014). Combining Transcranial Direct Current Stimulation and Tailor-Made Notched Music Training to Decrease Tinnitus-Related Distress-A Pilot Study. PloS One, 9(2), e89904.

Valle, A., Roizenblatt, S., Botte, S., Zaghi, S., Riberto, M., Tufik, S., ... \& Fregni, F. (2009). Efficacy of anodal transcranial direct current stimulation (tDCS) for the treatment of fibromyalgia: results of a randomized, sham-controlled longitudinal clinical trial. Journal of Pain Management, 2(3), 353.

Vanneste, S., Walsh, V., Van De Heyning, P., \& De Ridder, D. (2013). Comparing immediate transient tinnitus suppression using tACS and tDCS: A placebo-controlled study. Experimental Brain Research, 226(1), 25-31.

Varga, E., Kaya, E., Antal, A., Zimmer, M., Harza, I., Paulus, W., \& Kovacs, G. (2007). Cathodal transcranial direct current stimulation over the parietal cortex modifies facial gender adaptation. Clinical Neuroscience, 60, 474-479.

Vaseghi, B., Zoghi, M., \& Jaberzadeh, S. (2014). Does anodal transcranial direct current stimulation modulate sensory perception and pain? A meta-analysis study. Clinical Neurophysiology, 125, $1847-1858$.

Villamar, M. F., Volz, M. S., Bikson, M., Datta, A., DaSilva, A. F., \& Fregni, F. (2013). Technique and considerations in the use of $4 \times 1$ ring high-definition transcranial direct current stimulation (HD-tDCS). Journal of Visualized Experiments: JoVE, (77).

Wagner, S., Rampersad, S. M., Aydin, Ü., Vorwerk, J., Oostendorp, T. F., Neuling, T., ... \& Wolters, C. H. (2014). Investigation of tDCS volume conduction effects in a highly realistic head model. Journal of Neural Engineering, 11(1), 016002.

Weiss, M., \& Lavidor, M. (2012). When less is more: Evidence for a facilitative cathodal tDCS effect in attentional abilities. Journal of Cognitive Neuroscience, 24(9), 1826-1833.

Yau, J. M., Celnik, P., Hsiao, S. S., \& Desmond, J. E. (2014). Feeling Better Separate Pathways for Targeted Enhancement of Spatial and Temporal Touch. Psychological Science, 0956797613511467, 1-11.

Yuen, T. G., Agnew, W. F., Bullara, L. A., Jacques, S., \& McCreery, D. B. (1981). Histological evaluation of neural damage from electrical stimulation: Considerations for the 
selection of parameters for clinical application. Neurosurgery, 9(3), 292-299.

Zaehle, T., Beretta, M., Jäncke, L., Herrmann, C. S., \& Sandmann, P. (2011). Excitability changes induced in the human auditory cortex by transcranial direct current stimulation: Direct electrophysiological evidence. Experimental Brain Research, 215(2), 135-140.
Zaghi, S., Acar, M., Hultgren, B., Boggio, P. S., \& Fregni, F. (2009). Noninvasive brain stimulation with low-intensity electrical currents: Putative mechanisms of action for direct and alternating current stimulation. Neuroscientist, 1, 1-12.

Zatorre, R. J., \& Belin, P. (2001). Spectral and temporal processing in human auditory cortex. Cerebral Cortex, 11(10), 946-953. 